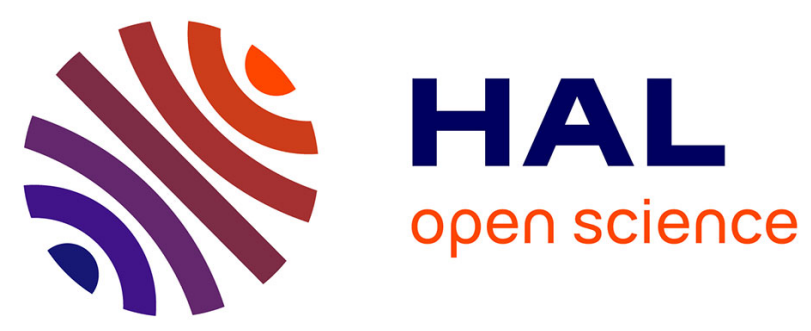

\title{
Nutrient dynamics at the sediment-water interface in a Mediterranean lagoon (Thau, France): Influence of biodeposition by shellfish farming activities
}

\author{
V. Mesnage, S. Ogier, G. Bally, Jean-Robert Disnar, Nathalie Lottier, K. \\ Dedieu, C. Rabouille, Yoann Copard
}

\section{To cite this version:}

V. Mesnage, S. Ogier, G. Bally, Jean-Robert Disnar, Nathalie Lottier, et al.. Nutrient dynamics at the sediment-water interface in a Mediterranean lagoon (Thau, France): Influence of biodeposition by shellfish farming activities. Marine Environmental Research, 2007, 63 (3), pp.257-277. 10.1016/j.marenvres.2006.10.001 . insu-00149946

\section{HAL Id: insu-00149946 https://hal-insu.archives-ouvertes.fr/insu-00149946}

Submitted on 29 May 2007

HAL is a multi-disciplinary open access archive for the deposit and dissemination of scientific research documents, whether they are published or not. The documents may come from teaching and research institutions in France or abroad, or from public or private research centers.
L'archive ouverte pluridisciplinaire $\mathbf{H A L}$, est destinée au dépôt et à la diffusion de documents scientifiques de niveau recherche, publiés ou non, émanant des établissements d'enseignement et de recherche français ou étrangers, des laboratoires publics ou privés. 
Nutrient dynamics at the sediment-water interface in a Mediterranean lagoon (Thau, France): influence of biodeposition by shellfish farming activities

\author{
Valérie Mesnage $^{\mathrm{a}^{*}}$, Sylvie Ogier ${ }^{\mathrm{a}}$, Gabriel Bally ${ }^{\mathrm{b}}$, Jean-Robert Disnar ${ }^{\mathrm{c}}$, \\ Nathalie Lottier ${ }^{\mathrm{c}}$, Karine Dedieu ${ }^{\mathrm{d}}$, Christophe Rabouille ${ }^{\mathrm{d}}$, Yoann Copard ${ }^{\mathrm{a}}$ \\ ${ }^{a}$ UMR CNRS 6143 «M2C », Université de Rouen, 76821 Mont-Saint-Aignan, France \\ ${ }^{b}$ Dépt. Dyneco Pelagos, Ifremer-Brest, BP 70, 29280 Plouzané , France \\ ${ }^{c}$ ISTO, UMR CNRS 6113, bât. Géosciences, Université d'Orléans, BP 6759, 45067 Orléans cedex 2, France \\ ${ }^{d}$ Laboratoire des Sciences du Climat et de l'Environnement, UMR CEA-CNRS, 91198 Gif-Sur-Yvette, France
}

\begin{abstract}
The Thau Lagoon, a French Mediterranean shallow lagoon, is the place of shellfish farming. The aim of the present work was to evaluate the role of this activity on nutrient exchange at the sediment-water interface in relation to organic matter (OM) sedimentation and degradation. Two stations inside (C5) and ouside (C4) the shellfish farming areas were sampled at 3 seasons. Porewater chemistry surveys and calculated diffusive fluxes were used to evaluate the trophic status of the Thau lagoon. Quantitative (Particulate Organic Carbon) as well as qualitative OM analysis (Hydrogen Index, Carbohydrates) were performed on sediments to assess OM characteristics. Results emphasized that surficial sediments at C5 are always more enriched in OM. Porewater nutrients concentrations are 10 to 20 times higher at C5 than at C4. In June 2003, the porewater profiles exhibit a sharp gradient at the bottom waters, indicating a hypereutrophic status, leading to an anoxic crisis.
\end{abstract}

* corresponding author. Tel.:33 (0)2 351469 47; fax: 33 (0)2 35147022

E-Mail address: valerie.mesnage@,univ-rouen.fr (V. Mesnage)

Keywords : Nutrients; Dissolved organic matter; Nutrients fluxes; Neutral carbohydrate; Sediment-water interface; Coastal waters; Eutrophication

\title{
1. Introduction
}

The French Mediterranean coast is bordered by several shallow lagoons formed during the lastest 10000 years at the favour of the lastest marine transgression. These lagoons, located in a rather densely populated transition zone between the continent and the sea, constitute very fragile ecosystems well adapted to study the impact of Man on the Environment. As a matter of fact, these lagoons, and especially Thau, suffer from eutrophication as a result of (i) excessive nutrient inputs from the catchment, (ii) very low water renewal (water residence time of about 3 months) and (iii) specific climate conditions (high temperature, limited rainfull periods, low tidal currents, Bacher et al. , 1996). 
Thau, the biggest of the lagoons, is the site of shellfish farming. The shellfish production zones cover $1 / 5$ of the lagoon area and its annual production represents about $15000 \mathrm{t}$. The continual immersion of farming structures involves an abundant epibiose development on the oysters-mussels cords. The presence of these heterotrophic organisms (oysters and epibionts) in the water column modifies the transfer and the transformation of organic matter (OM) within the lagoon ecosystem (Mazouni et al., 1996; 1998). For example, sedimentation fluxes have been estimated from 100 to $400 \mathrm{mg} \mathrm{C} . \mathrm{m}^{2} \cdot \mathrm{h}^{-1}$ in shellfish areas. These fluxes, 2 to 4 times higher than in the areas without shellfish, are susceptible to increase the sedimentation rate (Grenz et al. 1992). In addition, the combination of high OM productivity, high summer temperature $\left(25^{\circ} \mathrm{C}\right.$ water surface temperature), low wind speed, induces the rapid depletion of dissolved oxygen and subsequent anoxia (Harzallah \& Chapelle, 2002). Anoxic conditions develop in summer both at the sediment-water interface and at the bottom of the water column. These anoxic episodes, locally named "malaigues", induce a high turbidity and $\mathrm{H}_{2} \mathrm{~S}$ smell during the summer months with a large shellfish mortality.

Previous studies have established that the sediment compartment is a sink for particulate phosphate (Boström et al., 1982, 1988; Caraco et al., 1990). This compartment could also become a source through the release of dissolved species under well defined $\mathrm{pH}$ and Redox conditions (Boers, 1991; Song \& Müller, 1999). Numerous parameters influence the exchange of nutrients at the sediment-water interface and emphasize the influence of multi-environmental parameters such as bacterial activity (Gächter \& Meyer, 1993), iron-hydroxide chemistry or oxygen conditions (Maine et al., 1992; De Montigny et al. 1993). Moreover, OM buried in sediments may impact the nutrient release by forming refractory organo-metallic complexes with iron and phosphorus (Paludan and Jensen, 1995; De Groot and Golterman, 1993; Hirata, 1985). Even if these complexes are subjected to microbiological mineralisation as a carbon and an energy source, their low availability may delay the nutrient release. If this low bioavailable OM quantity exceeds the bacterial mineralisation capacity of the sediment, these complexes will accumulate in the sediment compartment as a 'residual organic phosphate' fraction (De Groot and Golterman, 1993) that will only be remobilised with difficulty. The sedimentary OM content is not sufficient to discuss the nutrients release at the sediment-water interface, measurements of OM quality and degradation rate being needed to access to the extent of degradation of sediment organic components.

The aim of the present work is to discuss the role of shellfish farming on the nutrient exchange dynamic at the sediment-water interface in two contrasted sites of the Thau Lagoon : inside and ouside the shellfish farming areas. A seasonal porewater survey was investigated at these two sites in Winter 2001-02, Spring 2002 and Summer 2003, reflecting contrasted trophic levels in the lagoon. As little is known on Thau sediment OM, this study is focussed on OM characterisation from the quantitative (Particulate Organic Carbon) as well as the qualitative (Hydrogen Index, Carbohydrates) point of view. The interpretation of OM degradation rate should allow take into account the influence of shellfish biodeposits on the exchange of nutrient at the sediment-water interface.

\section{Material and methods}

\subsection{Site}

The 'Thau' Lagoon, a Mediterranean shallow coastal lagoon is located in the South of France $\left(3^{\circ} 32^{\prime}\right.$ to $3^{\circ} 42^{\prime} \mathrm{E}$ and $43^{\circ} 20^{\prime}$ to $43^{\circ} 28^{\prime} \mathrm{N}$ ). Its total surface is about $75 \mathrm{~km}^{2}$ with a length of $19.5 \mathrm{~km}$ and a width of $4.5 \mathrm{~km}$. Its depth 
varies from 4 to 10 meters. At each extremities, the lagoon is connected to the sea inducing a water residence time of about 3 months.

Two different sampling stations were chosen in contrasted areas of the shallow lagoon: the first site (station C4) was located in the middle of the lagoon (N4324.018, E3 ${ }^{\circ} 36.703$; average depth: $8 \mathrm{~m}$.) and the second site (station

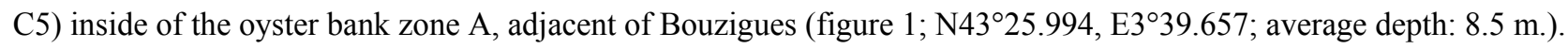

Fieldtrips were carried out, at the two sampling stations, at three different times of year, namely in (i) Winter 2001-02 (05/12/01 to $09 / 12 / 01$; insertion of diffusion samplers to be removed in January 2002 after 3 weeks equilibration), (ii) Spring 2002 (15/04/02 to 21/04/02; insertion of diffusion samplers in March 02, removal in the 18/04/02 after 3 weeks equilibration), (iii) Summer 2003 (19/05/03 to 23/05/03; insertion of diffusion samplers to be removed the 26/06/03 after one month equilibration).

\subsection{Sediment characteristics}

The two sampling sites present a grey silty clayey sediment containing shells without physical structures. The sediment is mainly constituted by fine silt (10 to $20 \mu \mathrm{m})$. The mixed layer, at the $\mathrm{C} 4$ site, is restricted to the upper $3 \mathrm{~cm}$. In contrast, the C5 site has a mixed layer of $10 \mathrm{~cm}$ depth (Schmidt et al. accepted, 2005). Composition of sediments has given the following composition: $\mathrm{CaO}=18.4 \%, \mathrm{MgO}=1.97 \%, \mathrm{~K}_{2} \mathrm{O}=1.71 \%, \mathrm{Na}_{2} \mathrm{O}=3.72 \%, \mathrm{Fe}_{2} \mathrm{O}_{3}=2.02 \%, \mathrm{Al}_{2} \mathrm{O}_{3}=8.54 \%$ (Péna \& Picot, 1991). At the C4 site, the porosity is constant with depth with a value around 0.85 . In contrast, the porosity of C5 site decreases from 0.90 at the sediment surface to 0.75 at $35 \mathrm{~cm}$ depth (Metzger et al. accepted, 2005). At the sediment surface to $40 \mathrm{~cm}$ depth, $\mathrm{pH}$ values vary from 8 to 8.4 at the $\mathrm{C} 4$ site and 7.4 to 8 at the C5 site (Metzger et al. accepted, 2005). The redox potential (Eh) in the sediment surface is about $200 \mathrm{mV}$ whatever the site and the season whereas the redox measured in the first $10 \mathrm{~cm}$ of sediment showed significant seasonal variation. The redox values decrease during the year: $\mathrm{Eh}=125 \mathrm{mV}$ in winter and $\mathrm{Eh}=-50 \mathrm{mV}$ in summer.

\subsection{Sampling techniques}

The pore water sampling was performed using diffusion samplers (Hesslein, 1976), with an inert polysulfone membrane of $0.2 \mu \mathrm{m}$ porosity (Millipore, Durapore). The diffusion sampler design employed consists of a $51.5 * 22 * 3$ $\mathrm{cm}$ Plexiglas sheet in which fixed volume $\left(5.6 \mathrm{~cm}^{3}\right)$ chambers are spaced at $1 \mathrm{~cm}$. Each diffusion sampler has two series of 40 chambers. In order to avoid oxygen contamination in the chambers, the diffusion samplers were bubbled with nitrogen in deionised water bath before their insertion. At the C5 and C4 sites at each sampling period, two diffusion samplers were inserted in the sediments, by scuba-divers, in an area of $2 \mathrm{~m}^{2}$, leaving 6 or 7 chambers above the sediment surface and 33 or 34 below. The equilibration time required for the diffusion sampler is 3 weeks according to Bally et al. (2005). Pore water samples were removed using plastic syringes, in a glove box filled with nitrogen to prevent the co-precipitation of phosphate with iron-hydroxide. The samples acidified with $1 \mathrm{~N} \mathrm{HCl}$ and stored in conditionned $5 \mathrm{ml}$ haemolysis tubes were frozen until analysed for phosphate (SRP), ammonia $\left(\mathrm{NH}_{4}^{+}\right)$and $\mathrm{Dissolved}^{+}$ Organic Carbon (DOC) determination.

Sediment cores $(\Phi=12 \mathrm{~cm}$ and length $=25 \mathrm{~cm})$ were sampled by scuba-divers with Plexiglas ${ }^{\circledR}$ corers, at the C4 and C5 stations, in April 2002. Coring operations were carried out very carefully in order to prevent any disturbance of the top sediment where the water content is very high (96\% at the sediment surface; $86 \%$ at $20 \mathrm{~cm}$ depth). Immediately after the sampling, the top $2 \mathrm{~cm}$ were cut into slices of $1 \mathrm{~cm}$, except for the 2 first $\mathrm{cm}$ which was cut into 
slices of $0.5 \mathrm{~cm}(0-0.5 \mathrm{~cm} / 0.5-1 \mathrm{~cm} / 1-1.5 \mathrm{~cm} / 1.5-2 \mathrm{~cm} / 2-3 \mathrm{~cm} / 3-4 \mathrm{~cm} / 4-5 \mathrm{~cm} /$ $. . / 19-20 \mathrm{~cm}$ for $\mathrm{C} 4$ and until 21-22 $\mathrm{cm}$ for $\mathrm{C} 5$ ). The sediment cakes obtained were stored in plastic bags filled with nitrogen and immediately frozen.

\subsection{Sediment analysis}

Rock-Eval pyrolysis (Espitalié et al., 1985) was used for global organic matter quantititive and qualitative characterisation. Two main parameters may be provided by this technique : Total Organic Carbon (here named Particulate Organic Carbon "POC") and the Hydrogen Index (HI) which depends on the hydrogen OM content and the corresponding $\mathrm{C} / \mathrm{H}$ (Espitalié et al., 1985). The POC and the $\mathrm{HI}$ are expressed in \% Organic Carbon weight and mg of Hydrocarbons per g POC (or mg HC. $\mathrm{g}^{-1} \mathrm{POC}$ ), respectively.

Rock-Eval ${ }^{\circledR}$ pyrolysis has been performed with an RE6 device of Vinci Technologies ${ }^{\mathrm{TM}}$. The analysis were carried out on $100 \mathrm{mg}$ of crushed samples with a temperature of $200^{\circ} \mathrm{C}(20 \mathrm{~min})$ up to $600^{\circ} \mathrm{C}_{\text {at }} 25^{\circ} \mathrm{C} \mathrm{min}^{-1} \mathrm{under}$ a $\mathrm{N}_{2}$ flow, followed by oxidation at $600^{\circ} \mathrm{C}$ for $7 \mathrm{~min}$ under an oxygen flow. All the analysis were performed in duplicate. Reproducibility determined after 68 analysis with the IFP 55000 reference material was $+/-2 \%$ for POC content and $+/-6 \%$ for HI (Disnar et al. 2003).

Carbohydrate analyses were performed on the top $(0-2 \mathrm{~cm})$ and the base $(13-22 \mathrm{~cm}$ in C5 core and 10-20 $\mathrm{cm}$ in $\mathrm{C} 4$ core) in order to characterize the availability of carbohydrate at the sediment-water interface in contrast with deeper sediment. The procedure used for carbohydrate analysis derives from previous works (Bethge et al. , 1966; Oades et al., 1970; Modzeleski \& Laurie, 1971; Cowie \& Hedges, 1984a). Briefly after hydrolysis (100 C; $3 \mathrm{~h}$.) with $0.5 \mathrm{M} \mathrm{H}_{2} \mathrm{SO}_{4}$ and cooling, an internal standard (6-deoxy-D-glucose; Wicks et al., 1991) is added to the hydrolysate. The anomeric carbohydrate mixture is equilibrated with lithium perchlorate $(0.2 \%)$ in pyridine (Bethge et al., 1966) and silylated with N,O-Bis(trimethylsilyl)trifluoroacetamide. Finally, the silylated carbohydrates were analysed on a Perkin-Elmer ${ }^{\mathrm{TM}}$ Auto System XL gas chromatograph. Peaks were identified through retention times and quantified using a standard mixture of eight neutral monosaccharides, namely, arabinose, rhamnose, ribose, fucose, xylose, mannose, galactose and glucose. Quantification was based on one of the major and better-resolved anomer peaks given by each studied compound (Bethge et al., 1966). Total carbohydrates contents were calculated as the sum of the compounds identified and quantified. Analytical errors varied between 2.6 and $13 \%$ depending on the type and the abundance of the compound considered (Ogier et al., 2001).

\subsection{Dissolved component analysis}

Phosphate (SRP) and ammonia $\left(\mathrm{NH}_{4}^{+}\right)$were measured using a colorimetric method (Stainton et al., 1977) with a Bran+Luebbe ${ }^{\mathrm{TM}}$ auto-analyser Continuous Flow Analysis, according to the methods of Treguer \& Le Corre (1975). The detection limits are $0.014 \mathrm{mg} \mathrm{l}^{-1}$ and $0.01 \mathrm{mg} \mathrm{l}^{-1}$ for phosphate and ammonia, respectively. DOC was analysed with a Shimatzu $5050^{\mathrm{TM}}$ TOC analyser with a detection limit of $1 \mathrm{mg} \mathrm{l}^{-1}$. Measurements precisions are $5 \%$ RSD determined from repeated measurements (5 times) of the same sample and standard samples (Bally et al., 2004).

\subsection{Method for calculating Nutrient diffusive fluxes}

The calculated diffusive fluxes were calculated using the first Fick's law adapted for sediments (I): 


$$
\mathrm{J}_{\mathrm{S}}=-\mathrm{D}_{\mathrm{s}} \times \frac{\mathrm{dC}_{\mathrm{i}}}{\mathrm{dx}}(\mathrm{I})
$$

Js : Calculated diffusive flux $\left(\mathrm{mmol} \cdot \mathrm{m}^{-2} \cdot \mathrm{d}^{-1}\right)$

$\varphi$ : Sediment porosity (dimensionless)

$\mathrm{D}_{\mathrm{s}}$ : Diffusion coefficient of the species in sediment $\left(\mathrm{m}^{2} \cdot \mathrm{d}^{-1}\right)$

$\frac{\mathrm{dC}_{\mathrm{i}}}{\mathrm{dx}}$ : Profile gradient $\left(\mathrm{mmol} . \mathrm{m}^{-4}\right)$

The diffusion coefficient in water $\left(\mathrm{D}_{\mathrm{w}}^{0}(\mathrm{X})\right)$ was corrected from the Stockes-Einstein formula (II \& III) given in Li \& Gregory (1976):

$$
\begin{gathered}
\mathrm{D}_{\mathrm{w}}^{0}\left(\mathrm{NH}_{4}{ }^{+}\right)=19.8+0.4(\mathrm{~T}-25) \\
\mathrm{D}_{\mathrm{w}}^{0}\left(\mathrm{PO}_{4}^{3-}\right)=7.36+0.16(\mathrm{~T}-25)
\end{gathered}
$$

with

$\mathrm{D}_{\mathrm{w}}^{0}\left(\mathrm{PO}_{4}{ }^{3-}\right)$, Diffusion coefficient in water for $\mathrm{PO}_{4}{ }^{3-}\left(\mathrm{m}^{2} \cdot \mathrm{d}^{-1}\right)$

$\mathrm{D}_{\mathrm{w}}^{0}\left(\mathrm{NH}_{4}^{+}\right)$, Diffusion coefficient in water for $\mathrm{NH}_{4}^{+}\left(\mathrm{m}^{2} \cdot \mathrm{d}^{-1}\right)$

$\mathrm{T}$, sediment temperature $\left({ }^{\circ} \mathrm{C}\right)$

The diffusion coefficient in sediment is calculated from the formula (IV)

$$
\mathrm{D}_{\mathrm{s}}(\mathrm{X})=\frac{\mathrm{D}_{\mathrm{w}}^{0}(\mathrm{X})}{\theta^{2}}(\mathrm{IV})
$$

$\theta^{2}$ is the tortuosity obtained from the formula $\mathrm{V}$ (Boudreau, 1996)

$$
\theta^{2}=1-2 \ln \varphi(\mathrm{V})
$$

The porosity and the temperature used in flux calculation are reported in table 1.

\section{Results}

\subsection{Bulk organic matter characterization (POC and HI)}

At C5, Particulate Organic Carbon (POC) contents decreases sharply from $4.4 \%$ at the top of the core to $3.3 \%$ at $1.75 \mathrm{~cm}$ depth. This decreasing trend continues smoothly down to $8 \mathrm{~cm}$ depth to reach a value of $1.7 \%$. Below this depth, POC contents remain rather constant around 2\% down to the base of the core (Fig. 5a, Table 3a). The Hydrogen Index $\mathrm{HI}$ values (hydrocarbon mg per $\mathrm{g}$ of Organic Carbon), remain constant with values around $370 \mathrm{mg} \mathrm{HC} \mathrm{g}^{-1} \mathrm{POC}$ in the upper $5 \mathrm{~cm}$ of the core. Below this depth, HI values first decrease downward to reach a value of $323 \mathrm{mg} \mathrm{HC} \mathrm{g}^{-1}$ POC at $8 \mathrm{~cm}$ depth (Fig. 6a), then fluctuate between 217 and $335 \mathrm{mg} \mathrm{HC}^{-1}$ POC (Table 3a).

At $\mathrm{C} 4$, POC contents increase slightly from $3 \%$ at the top of the core to $3.2 \%$ at $2 \mathrm{~cm}$ depth. Between $2 \mathrm{~cm}$ to $8 \mathrm{~cm}$ POC decreases with depth to reach a value of ca. $2.6 \%$ at $8 \mathrm{~cm}$ depth and below this depth values remain constant down to $11 \mathrm{~cm}$ depth. Below $11 \mathrm{~cm}$, POC contents vary between 2.8 to $4.2 \%$ (Figure 5b, Table 3b). Hydrogen Index (HI) values decrease downcore from $354 \mathrm{mg} \mathrm{HC} \mathrm{g}^{-1} \mathrm{~g}$ POC at the sediment water interface to $303 \mathrm{mg} \mathrm{HC} \mathrm{g}^{-1} \mathrm{~g}^{\mathrm{POC}}$ at the base of the core $(20 \mathrm{~cm}$ depth) (Table $3 \mathrm{~b})$. 


\subsection{Carbohydrate analysis}

At C5, the total neutral carbohydrate concentrations decrease sharply with depth with a value of $3.6 \mathrm{mg} \mathrm{g}^{-1}$ (dry weight) near the sediment surface, $3.2 \mathrm{mg} \mathrm{g}^{-1}$ at $2 \mathrm{~cm}$ depth and only $1.3 \mathrm{mg} \mathrm{g}^{-1}$ at $22 \mathrm{~cm}$ depth (Table $3 \mathrm{a}$ ). These compound concentrations indicate that carbohydrates contribute only to 7 to $12 \%$ of POC. In the surficial sediments $(0-$ $2 \mathrm{~cm})$ individual neutral carbohydrates are dominated by rhamnose $(24 \%)$ and fucose $(21 \%)$, followed by glucose (15 $\%)$, galactose $(12 \%)$, xylose (11\%), arabinose (9\%) and mannose (8\%) (Fig. 6a; Table 3a). Ribose which was often below the detection limit is thus not discussed further. At the base of the core $(13-22 \mathrm{~cm})$, neutral carbohydrates are dominated by fucose $(24 \%)$ and rhamnose (18\%), followed by glucose (14\%), arabinose (14\%), xylose (12\%), mannose (9\%) and galactose (9\%) (Fig.6c).

At $\mathrm{C} 4$, the total neutral carbohydrate concentration presents a rather high top core $(0-2 \mathrm{~cm})$ value of $2.5 \mathrm{mg} \mathrm{g}^{-1}$. At $10 \mathrm{~cm}$ depth, carbohydrate concentrations are only $1.8 \mathrm{mg} \mathrm{g}^{-1}$. Below this depth values increase slighly with large variations between 2.1 and $3.2 \mathrm{mg} \mathrm{g}^{-1}$ (Table $3 \mathrm{~b}$ ). These compound concentrations indicate that carbohydrates account for $5.4 \%$ to $10.7 \%$ of the POC. In the surficial sediment $(0-2 \mathrm{~cm})$ the weight percentages of individual neutral carbohydrates are dominated by glucose $(23 \%)$ and fucose $(22 \%)$, followed by xylose $(13 \%)$, galactose $(13 \%)$, arabinose (11\%), mannose (10\%) and rhamnose (8\%) (Fig. 6b Table 3b). Ribose is present at low concentrations and often below the detection limit. At the base of the core $(10-20 \mathrm{~cm})$, the weight percentages of individual neutral carbohydrates in sediments are dominated by glucose $(20 \%)$, fucose $(19 \%)$ and rhamnose $(17 \%)$, followed by xylose (15\%), galactose (14\%), mannose (9\%) and arabinose (8\%) (Fig. 6d).

\subsection{Nutrient porewater profiles}

\section{Soluble Reactive Phosphorus (SRP)}

At the C5 sampling station, in the bottom waters (up to $7 \mathrm{~cm}$ above the sediment-water interface), Soluble Reactive Phosphorus (SRP) concentrations were at the lowest in Winter (January 2001, Fig. 2a), and Spring (April, 2002, Fig. 2b) and then varied between 0.1 and $4 \mu$ M. In contrast, in Summer (June 2003, Fig. 2c), at the same site, SRP concentrations reached very high levels in the bottom waters: $20 \mu \mathrm{M}$ at $10 \mathrm{~cm}$ over the water-sediment interface, up to $60 \mu \mathrm{M} 5 \mathrm{~cm}$ below and finally 10 times higher values $(600 \mu \mathrm{M})$ at the sediment interface. Always in summer, SRP concentrations decreased slowly below the sediment surface to reach $100 \mu \mathrm{M}$ at $5 \mathrm{~cm}$ depth.

At the C4 sampling station, SRP concentrations reached about $1 \mu \mathrm{M}$ in the bottom waters. However, these concentrations showed no change with depth. Moreover, no SRP concentration gradient was observed in the sediment at this site throughout the year.

\section{Ammonia concentrations $\left(\mathrm{NH}_{4}^{+}\right)$}

At the C5 sampling station, ammonia concentrations $\left(\mathrm{NH}_{4}^{+}\right)$fluctuated between 15 to $30 \mu \mathrm{M}$ in Winter (Fig. 3a) and Spring (Fig. 3b) in the bottom waters. In contrast, in Summer (June 2003, Fig. 3c) they increased sharply, up to values of $500 \mu \mathrm{M}$, i.e. about 10 times more than during the previous sampling periods.

$\mathrm{NH}_{4}^{+}$profiles are also quite similar to those obtained for the other dissolved species (i.e. SRP and DOC). Again all nutrients gave similar profiles namely with a gradient between -5 and $-15 \mathrm{~cm}$, except for the Summer period (June 2003), where the concentration gradient was located in the bottom waters. The concentrations reached values of about $8000 \mu \mathrm{M}$ at the sediment-water interface. Thus a concentration gradient is present in the bottom waters, but not in the sediment under the interface. 
The porewater chemistry at the C4 sampling station is really different. At this site concentrations levels were low $(<50 \mu \mathrm{M})$ and these was no concentration gradients, the profiles being vertical (Fig. 3d, 3e).

\section{Dissolved Organic Carbon (DOC)}

At the $\mathrm{C} 5$ site the bottom waters $(5 \mathrm{~cm}$ above the sediment-water interface) showed Dissolved Organic Carbon (DOC) contents increased sharply in Summer (June 2003, Fig. 4c) to reach values up to $10000 \mu \mathrm{M}$. Then, DOC concentrations in the bottom waters were about 20 times higher than in Spring and Winter. In addition, a concentration gradient is observed in the bottom waters but not in the sediment as usually expected.

During Winter and Spring at C5, DOC concentrations increased continuously with depth in the sediments, to delineate a gradient down to $15 \mathrm{~cm}$ below the sediment-water interface. Below, DOC concentrations remained constant, in Spring, with values around $2000 \mu \mathrm{M}$. The variations of DOC concentrations with depth were better marked in Spring than in Winter. Because at this later season, results exhibit values from 1500 to $6000 \mu \mathrm{M}(-15 \mathrm{~cm}$ depth). It is worth underling that whatever the nutrients considered, it delineates profiles comparable to those of DOC, namely with a steep gradient between 5 and $15 \mathrm{~cm}$ depth.

In Summer (June 2003, Fig. 4c), the sharp DOC concentration gradient which was observed in the bottom waters, was not accompanied by any marked concentration change with depth in the sediment where DOC levels raised up to $20000 \mu \mathrm{M}$ of Carbon.

At the C4 sampling station, DOC profiles showed the same shape than those already described for SRP i.e. without any change all over the $30 \mathrm{~cm}$ of water and sediment investigated. DOC concentrations reached about $500 \mu \mathrm{M}$ in the bottom water and in the sediment in Winter and Spring (Fig. 4 d,e).

\subsection{Diffusive nutrients fluxes}

Fluxes have been calculated from concentration gradients observed for the nutrients profiles (Figs 2, 3 and 4). During Winter and Spring, these gradients were located between 5 and $15 \mathrm{~cm}$ below the sediment-water interface. At C5 station, calculated flux values fluctuated from 0.62 to $1.0 \mathrm{mmol} . \mathrm{m}^{-2} \cdot \mathrm{d}^{-1} \mathrm{NH}_{4}^{+}$and from 0.3 to $0.14 \mathrm{mmol}^{-2} . \mathrm{d}^{-1} \mathrm{PO} 4$ for Winter and Spring, respectively (Table 2). In contrast, at C4, the calculated fluxes values fluctuated from 0.2 to 0.05 mmol.m $\mathrm{m}^{-2} \cdot \mathrm{d}^{-1} \mathrm{NH}_{4}^{+}$and from 0.03 to $0.02 \mathrm{mmol} \cdot \mathrm{m}^{-2} \cdot \mathrm{d}^{-1} \mathrm{SRP}$, for Winter and Spring, respectively (Table 2). Whatever the season, a spatial variation is evident, with fluxes about 10 times higher at $\mathrm{C} 5$ than at $\mathrm{C} 4$.

In Summer (June 2003) at C5 site, concentration gradients were not located below the sediment water interface (- $5 \mathrm{~cm}$ depth), but in the bottom waters (Figs $2 \mathrm{c}$ and 3c). High $\mathrm{NH}_{4}{ }^{+}$and SRP flux values have been derived from these concentration gradients in the bottom waters $\left(10,7 \mathrm{mmol} \cdot \mathrm{m}^{-2} \cdot \mathrm{d}^{-1}\right.$ and $0.96 \mathrm{mmol} \cdot \mathrm{m}^{-2} \cdot \mathrm{d}^{-1}$ or respectively for $\mathrm{NH}_{4}^{+}$and SRP) (Table 2).

\section{Discussion -}

4.1 Nutrients profile, a tool to assess ecosystem trophic levels 
As generally observed in mediterranean shallow coastal lagoons, the phosphate inputs originated from urban and agricultural effluents. In the Thau lagoon, these inputs have decreased by a half from 1971 to 1996 as a result of an improvement in wastewater treatment on the Thau catchment-coastal lagoon system (La Jeunesse \& Elliot 2004). Over 30 years monitoring of water-column chemistry highlighted the decrease of phosphate concentrations. In the Seventies, the average phosphate concentration was $6 \mu \mathrm{M}$, increasing to $10 \mu \mathrm{M}$ during anoxic summer periods. In contrast, the average phosphate concentration, actually measured in the water column, fluctuated from 0.04 to $1.2 \mu \mathrm{M}$. The decrease of $90 \%$ of annual mean phosphate concentration in the water column from 1971 to 1994 (Souchu et al. 1998) can be explained by the reduction of domestical effluents but also but the changes in land-use by an exceptional decrease of vineyards areas (La Jeunesse et al. 2002). On the other side, phytoplanctonic biomass is present in higher concentrations in the lagoon than in sea water, with an average chlorophyll a of $2 \mu \mathrm{g} / 1$ with maxima of $5 \mu \mathrm{g} / \mathrm{l}$ in summer periods. This primary production depicts a relatively high trophic level in the lagoon. During summer, OM degradation and nutrient release at the sediment-water interface trigger a high phytoplanctonic activity in the water column, particularly in shellfish areas (Casellas et al. 1990; Plus et al. 2001).

The knowledge of porewater chemistry is a prerequisite for assessing nutrient dynamic at the sediment-water interface. The presence of significant amounts of OM buried in the sediments is probably the main factor influencing nutrients fluxes at the sediment-water. As a matter of fact, the shape of nutrient profiles reflects the presence of organic matter (OM) layers undergoing mineralisation and thus acting as a source of dissolved nutrients as $\mathrm{C}, \mathrm{N}$ and $\mathrm{P}$. In coastal shallow lagoons, OM inputs originate mainly from land, in the form of plant residues, or in situ, in the form of "normal" phytoplankton production plus shellfish biodeposits. Indeed, the nutrient profiles led us to follow OM mineralization over depth. At the C5 station the sediments are anoxic. As a matter of fact, the depth of oxygen penetration is, at a maximum, limited to $5 \mathrm{~mm}$ in winter and $0.5 \mathrm{~mm}$ in summer (Dedieu et al. accepted 2005). This anoxic sedimentary environment entails anaerobic OM degradation, with oxidation reactions successively driven by the reduction of Mn and Fe oxides, then of sulphates and finally by methane fermentation processes (Song \& Müller, 1999). All these processes are known to release monomeric low molecular weight compounds such as organic acids which may acidify the porewaters (Burdige \& Gardner, 1998). The measurements of porewater redox-sensitive species at the C5 station (Metzger et al. accepted 2005) confirm the establishment of such anaerobic OM degradation. Another consequence of this process is the greater acidity of the sediment at C5 station than at C4 station over the upper $40 \mathrm{~cm}$ (Metzger et al. accepted, 2005). Moreover, these observations are consistent with the presence of more labile OM at the $\mathrm{C} 5$ station than at $\mathrm{C} 4$.

Discussion on the trophic level of aquatic ecosystems is often approached using porewater gradients. In oligotrophic ecosystems, the nutrient profiles are vertical, i.e. the concentrations remain at the same level throughout the water column and the sediment. In contrast, in eutrophic ecosystems nutrients profiles exhibit sharp gradients near the sediment-water interface. At C4 station, especially in winter, nutrients profiles exhibit a vertical shape, reflecting low biological activity consequentive to low input of biodegradable OM. In contrast, at the C5 station, nutrient profiles delineate high gradients in summer. The nutrient concentration increased down to $10 \mathrm{~cm}$ below the sediment-water interface (Figs 2c, 3c, 4c). Above, the nutrient profiles are vertical, with the same concentration levels in the water column than in the sediment. One hypothesis for this vertical profile is the homogeneisation of the sediment, explained by the $10 \mathrm{~cm}$ upper mixed layer in relation to rather high biological activity at the $\mathrm{C} 5$ station (Schmidt et al. accepted 2005) 
Previous works on porewater nutrient chemistry, in the Thau laggon (Mesnage, 1994, Mesnage \& Picot, 1995, Meztger et al. accepted, 2005), have demonstrated that nutrient concentrations (SRP and Ammonia) were three times higher inside the oyster banks than outside. Moreover, a sharp concentration gradient that appears below the sedimentwater interface $(-2 \mathrm{~cm})$ evidences nutrient accumulation in porewaters (Mesnage, 1994). The impact of oysters on phosphate accumulation in surface sediments under the influence of their pseudo-faeces was also demonstrated: sediments inside of shellfish bank zone (zone B, Fig. 1) were more loaded in particulate phosphorus than those outside of the shellfish farming zone (Chapelle et al. 1994).

In contrast, with these previous works (Mesnage \& Picot, 1995; Metzger et al. Accepted 2005), the most relevant fact in the present study, is the shape of nutrient porewater profiles measured in summer 2003. Indeed, these profiles have a very uncommun shape exhibiting a transient consequence of this shellfish impacted ecosystem. The concentration gradient is not limited to the 10 first $\mathrm{cm}$ below the water-sediment interface, instead, it extends above the sediment-water interface, at the base of the water column. This kind of profile (Figures 2a, 3a and 4a) is very close to the theorical one, described by Enell \& Löfgren (1988), for shallow eutrophic lagoons exposed to high organic matter inputs (fish farming, phytoplankton or macro-algae sedimentation following the spring bloom). Thus, geochemical porewater results at $\mathrm{C} 5$, indicate a great seasonal variation evidenced by important increase of nutrients concentrations from Winter to Summer and provide a useful tool to evaluate the aquatic ecosytems trophic level, the difference between Summer and Winter nutrients concentrations being more pronounced in eutrophic ecosystems.

\subsection{Organic matter buried in sediments, influence on nutrient release}

The specific shape of nutrients porewater profiles in Summer 2003 is also supported by the data obtained on organic matter buried in the sediments. Indeed, POC values (3 to $4 \%$ in the surficial sediments), are in the range of those found in carbon-rich aquatic ecosystems especially in other impacted lagoons (Crawford et al., 2003). Such high values suggest a very probable contribution of shellfish feces to the OM buried in sediments. As a matter of fact, According to the literature, Mediterranean surficial sediments present POC contents lower than $1 \%: 0.7$ to $0.9 \%$ in Gulf of Lions (Accornero et al., 2003), 0.3 to $0.82 \%$ in Cretan sea (Gogou \& Stephanov, 2004). Others shallow lagoons in the world also present POC values in the same 0.1 - $2.8 \%$ range (Rigollet et al., 2004; Paez-Osuna et al., 1998). When, surficial lagoons sediments present higher POC values (i.e. $3<\mathrm{POC}<8 \%$ ), it is always in a particular context e.g. at sewage outfall (Mudge et al., 1998) or within shellfish farming zones (Crawford et al., 2003).

The combination of a higher sedimentation rate (Grenz et al. 1992) and higher POC values in the sediment (Figure 5a) ensure a much higher OM flux at C5 than at C4. The variations of the Hydrogen Index (HI) values at both these sites also reflect differences in OM composition. While the significance of POC content is straightforward, the HI index is related to the hydrogen content of organic matter and is both dependent on its biological origin (marine and/or terrestrial) and its degradation state (Espitalié et al., 1985). As generally assumed, a HI value higher than $600 \mathrm{mg} \mathrm{HC}^{-}$ ${ }^{1}$ POC in immature sediments, represents a lacustrine material enriched in hydrocarbonaceous moieties. An organic material with a HI ranging between 300 and $600 \mathrm{mg} \mathrm{HC} \mathrm{g}^{-1}$ POC often originates from algae (e.g. phytoplankton). Finally, a material with a HI lower than $300 \mathrm{mg} \mathrm{HC} \mathrm{g}^{-1} \mathrm{POC}$ is poor in hydrocarbonaceous moieties and usually represents an organic material derived from higher plants (Espitalié et al., 1985; Tissot \& Welte, 1984). Organic

material of the two sampling stations present $\mathrm{HI}$ values comprised between 300 and $350 \mathrm{mg} \mathrm{HC} \mathrm{g}^{-1}$ POC suggesting a dominant contribution from autochthonous phytoplanktonic production. However, in the top sediment layer $(0-2 \mathrm{~cm})$, 
HI values are slightly but significantly higher in C5 core than in the C4 one. This might indicate an OM content richer in hydrocarbonaceous moieties at C5 than at C4 and thus supposedly more able to sustain microbial activity.

At the C5 sampling station, the sharp POC decrease may be the result of bacterial OM assimilation or mineralisation. These processes are enhanced by the bioturbation in the surface sediment. Indeed, a mixed layer of 10 $\mathrm{cm}$ in thickness has been reported at the top of the core (see section 4.1). These processes easily explain why a decrease in HI values (Figure 5) is observed down to $10 \mathrm{~cm}$. Moreover, OM degradation is known to favour a preferential attack of hydrogen-rich compounds (Anderson and Johns, 1986). In addition, DOC is considered as an OM degradation product (Chang and Berner, 1999). Thus, high DOC fluxes measured in Summer at C5 may attest a high OM degradation rate. All these processes may explain this sharp HI decrease and the resulting high nutrient availibility.

In contrast, at the $\mathrm{C} 4$ site, the surface mixed layer $(0-3 \mathrm{~cm})$, exhibits constant POC and HI values. This confirms the refractory property of OM and/or the balance between OM degradation and OM buried in sediments. Below $3 \mathrm{~cm}$ depth, a concomitant and progressive decrease in POC and HI values may result from a slight consummation of $\mathrm{OM}$ by microbial community through diagenesis. To conclude, in contrast to $\mathrm{C} 4$, , analyses at $\mathrm{C} 5$ revealed both stronger bacterial activities enhanced by the availability of nutrients and a thicker mixing layer implying significant $\mathrm{OM}$ oxidation. DOC fluxes increase as a result of OM degradation.

Global OM quantitation and characterisation by POC and HI measurements have been supplemented by neutral carbohydrate analysis. Carbohydrates are usually present in lower quantities in phytoplankton (and bacteria) than in land plants where they are dominant especially as structural components, namely cellulose, hemicelluloses and pectin. However, in all cases they present the advantage of being easily metabolisable that makes them good tracers of microbial activity. The rather low carbohydrate content of the studied sediments indicates that these compounds have most probably been already actively recycled in the water column.

The major possibilities of distinction of potential OM sources through neutral carbohydrate analysis are summarized in Table 4. Accordingly, the high levels of rhamnose (followed by fucose) in the upper C5 sediment layers were attributed to heterotrophic microorganisms that developed in bottom waters, mostly at the expense of the primary production (mainly diatoms and cyanaobacteria). The decrease of rhamnose in the sediment was attributed to an easier recycling of the microbial material than that of the primary production, fucose included. Similar features than in the C5 core have recently been observed in an eutrophic lake (Ogier et al., 2001). Indeed, the predominance of non ubiquitous dominant compounds such as fucose and rhamnose, strongly suggest an autochthonous organic production from phytoplankton and/or bacterial material (e.g. Moers et al., 1990). Therefore, quantitation as well reactivity of OM, through carbohydrates analysis depict a higher OM accumulation and also more biodegradable OM at the C5 station than in C4. Thus, the rapid turn-over of autochthonous OM (phytoplancton, oysters-mussels feces, micro-organisms...) should impact the dissolved exchange processes at the sediment water interface of the Thau lagoon.

\subsection{Diffusive nutrients fluxes, relationship with sedimentary OM load}

Whatever the season, calculated diffusive fluxes values were always higher at $\mathrm{C} 5$ station than at $\mathrm{C} 4$. In summer (June 2003) at C5, diffusive nutrients fluxes were 10 times higher than at other seasons. This could be primarily explained by the quantity and the quality of the OM buried in the sediments. Others flux measurements, in summer, in 
an area also subject to biosediment deposition, did not give such high fluxes values (Mesnage 1994). Furthermore, concentrations gradients existed in sediments but not in the bottom waters, except in summer (Metzger et al. accepted, 2005). The later discrepancy could probably be explained by the fact that our porewater survey (retrival of dialyser sampler) occurred one month later after that of Metzger et al. (accepted, 2005).

Combined with the prevailing high temperatures, low wind and limited water circulations, the nutrient gradient in the bottom waters can be taken as an indicator of the dystrophic status of the ecosystem preceding the onset of an anoxia episode ("malaigues"). In addition, oyster farming zone A (Fig. 1) is little exposed to the winds. The water exchange between the lagoon and the Mediterranean Sea is limited by two narrow mouths and drained by numerous, small temporary rivers. These hydrologic conditions create a weak renewal of water in the Thau lagoon (Bacher et al., 1996), insufficient to remove the organic matter (feces, pseudo-feces) produced by oysters. The impact of oyster farming installations on the sedimentation rate and current speed has been demonstrated and evaluated. Previous studies have shown that biodeposits increased the sedimentation rate and that current speed can be reduced by around $60 \%$ (Grenz et al. 1992). Recent modelling of anoxia crisis in the Thau Lagoon, has defined the main controlling factors : wind speed and the presence of oyster tables (Chapelle et al., 2001). Moreover, the anaerobic degradation of organic oyster biodeposits is enhanced by the semi-enclosed area (lower current efficency) and the increase of the water column temperatures during Spring and Summer months. Trophic status as well as nutrient gradients in the bottom waters depict the particular situation preceding an anoxia crisis. As mentioned above, such a crisis effectively occurred with a high intensity, in August 2003, in the Thau Lagoon.

\section{Conclusion}

Higher deposition rate and higher OM concentration both under the particulate (POC) and the dissolved form (DOC), entail greater OM fluxes at the C5 station in the shellfish production zone, than at the C4 site in open waters. The geochemical discrepancy between both these two sites is true whatever the season and could be, at least primarily, simply explained by the contribution of oyster feces to sediment load.

The Hydrogen Index that gives a rough estimate of quality of the OM depicts a material richer in hydrocarbon and more biodegradable at $\mathrm{C} 5$ station than at C4. This is also in agreement with the porewater chemistry which revealed nutrients fluxes to be always 10 times higher at C5 than at C4. Neutral carbohydrate analysis confirms the labile character of OM in the surficial sediment at this site (C5). Indeed, fucose and glucose, the main carbohydrates measured in the surficial sediments suggest in situ phytoplanktonic production to be the main OM source.

Porewater profiles revealed the trophic status at the C5 station At C5, nutrient profiles showed a deep seasonal variation between winter and summer. Sharp gradients that have been evidenced below the sediment-water interface also extended above, in the bottom waters, in summer. The presence of such nutrients gradients at the bottom of the water column, in June 2003, is an indication of an impending anoxia crisis, which occured in August 2003 immediately after our field survey.

All our results (on particulate and dissolved organic species) point to a biogeochemical gradient between the C5 and C4 stations. Indeed, nutrients exchange dynamic is higher at C5 station, proving the impact of oysters farming 
in the buried labile OM. With its rapid turn-over, in situ OM production controls nutrients exchange at the sedimentwater interface.

\section{Acknowledgements}

This study was supported by a national French research program PNEC-ART1 "Microbent". We acknowledge Ifremer-Sète for providing the field-laboratory and a research boat. We would also like to thank: B. Bombled , J-J. Bourrand, D. Jézéquel, G. Sarasin, and the "COM" team for their assistance and specially for diving during the cruises, Dr. John Taylor for his very helpful comments and corrections of the English translation and D. Kéravis for Rock-Eval pyrolyses.

\section{References}

Accornero, A., Picon, P., De Bovée, F., Charrière, B., Buscail, R. (2003). Organic carbon budget at the sediment-water interface on the Gulf of Lions continental margin. Continental Shelf Research 23, 1, 79-92.

Anderson, K.B., Johns, R.B. 1986. Oxidation studies of Australian coals. I. Aliphatic and aromatic hydrocarbon centres of oxidative attack. Organic Geochemistry, 9, 5, 219-224.

Bally, G., Mesnage, V, Deloffre, J., Clarisse, O., Lafite, R., Dupont, J-P. (2004). Chemical characterization of porewaters in an intertidal mudflat of the Seine Estuary : relationship with erosion-deposition cycles. Marine Pollution Bulletin, 49, 163-173.

Bally G., Mesnage V., Verney R., Clarisse O., Dupont J-P., Ouddanne B., Lafite R.(2005). Dialysis porewater sampler: a strategy for time equilibration optimization. In Phosphates in Sediments, Proceedings of the $4^{\text {th }}$ International Symposium. (Ed) Seranno L. \& Golterman H.L. (Pub.) Backhuys, the Netherlands. 9-20.

Bacher, C., Millet, B., Vaquer, A. (1996). Modelling the impact of cultivated filter-feeders on phytoplanctonic biomass of the Thau lagoon (France). Compte-Rendu de l'Académie des Sciences, Paris, Sciences de la Vie/Life sciences, 320, 73-81.

Barkers, S.A., Somers, P.J. (1970). Bacterial and fungal polysaccharides. In: Pigman, W.Horton D (Eds), The Carbohydrates: Chemistry and Biochemistry, IIB. Academic Press, New-York, pp. 569-587.

Bethge, O., Holmström, C. Juhlin, S. (1966). Quantitative gas chromatography of mixtures of simple carbohydrate. Svenk Papper-Stidning, 69, 60-63.

Bhosle, N.B., Sankaran, P.D., Wagh, A.B. (1992). Monosaccharides composition of suspended particles from the Bay of Bengal. Oceanologica Acta, 15, 279-286.

Boers, P. (1991 ).The influence of pH on phosphate release from lake sediments. Water Research, 25, (3) 309-311. 
Bölter, M., Dawson, R. (1982). Heterotrophic utilisation of biochemical compounds in Antartic waters. Netherland Journal of Sea Research, 16, 315-332.

Boon, J.J., Hines, H., Burligame, A.L., Klok, J., Rijpstra, W.I.C., Leeuw, J.W.D., Edmunds, E.K., Eglinton, G. (1983). Organic geochemical studies of Solar Lake laminated cyanobacterial mats. In Bjoroy M. (Eds), Advances in Organic Geochemistry 1981. John Wiley,(pp. 207-227).

Boudreau, B.P. (1996). The diffusive tortuosity of fine-grained unlithified sediments. Geochimica and Cosmochimica Acta, 60, 3139-3142.

Boström, B., Jansson, M., Forsberg, C. (1982). Phosphorus release from lake sediments. Archives für Hydrobiologie Beih. Ergebnis., 18, 5-59.

Boström, B., Andersen, J.M., Fleischer, S., Jansson, M. (1988). Exchange of phosphorus across the sediment-water interface. Hydrobiologia, 170, 229-244.

Burdige, D. J. and K. G. Gardiner (1998). Molecular weight distribution of dissolved organic carbon in marine sediment porewaters. Marine chemistry 62: 45-64.

Caraco, N.F., Cole, J.J., Likens, G.E. (1990). A comparison of phosphorus immobilization in sediments of freshwater and coastal marine systems. Biogeochemistry, 9, 277-290.

Casellas, C., Pena, G., Picot, B., Illes, S., Bontoux, J. (1990). Nutrients in Thau Lagoon: Grouping of contiguous geographical zones. Water Research 12: 1479-1489

Chapelle, A., Mesnage, V., Mazouni, N., Deslous-Paoli, J-M., Picot, B. (1994). Modélisation des cycles de l'azote et du phosphore dans les sédiments d'une lagune soumise à une exploitation conchylicole. Oceanologica Acta, 17, (6) 609620.

Chapelle, A., Lazure, P., Souchu, P. (2001). Modélisation numérique des crises anoxiques (malaïgues) dans la lagune de Thau (France). Oceanologica Acta, 24 supplément, S87-S97.

Chang, S., Berner, R.A. (1999). Coal weathering and the geochemical carbon cycle. Geochimica and Cosmochimica Acta. 63, (19/20) 3301-3310.

Crawford, C. M., Macleod, C. K., Mitchell, I. M. (2003). Effects of shellfish farming on the benthic environment. Aquaculture, 224, (1-4), 117-140.

Cornett, R.J., Rigler, F.H. (1987). Decomposition of seston in the hypolimnion. Canadian Journal of Fisheries and Aquatic Science, 44, 146-151. 
Cowie, G.L., Hedges, J.I. (1984). Carbohydrate sources in a coastal marine environment. Geochimica et Cosmochimica Acta, 48, 2075-2087.

Dedieu, K., C. Rabouille, Thouzeau, G., Jean, F., Chauvaud, L., Clavier, J., Mesnage, V., Ogier, S. (accepted in Estuarine Coastal and Shelf Sciences, octobre 2005). Benthic O2 distribution and dynamics in a lagoon ecosystem : insitu microelectrodes study.

De Montigny, C., Prairie, Y., Boers, P., Cappenberg, T., Van Raaphorst, W. (1993). The relative importance of biological and chemical processes in the release of phosphorus from a highly organic sediment. Hydrobiologia, 253, 141-150.

Disnar, J.R., Guillet, B., Keravis, D., Di-Giovanni, C., Sebag, D. (2003). Soil organic matter (SOM) characterization by Rock-Eval pyrolysis: scope and limitations. Organic Geochemistry, 34, (3) 327-343.

Enell, M., Löfgren, S. (1988). Phosphorus in interstital water: methods and dynamics Hydrobiologia, 170, $103-132$.

Espitalié, J., Derro, G., Marquis, F. (1985). La pyrolyse Rock-Eval et ses applications. Revue de l'Institut Français du Pétrole, 40, 563-579.

Gächter, R., Meyer, J.S. (1993). The role of microorganisms in mobilization and fixation of phosphorus in sediments. Hydrobiologia 253, 103-121.

Gogou, A., Stephanou, E. G. (2004). Marine organic geochemistry of the Eastern Mediterranean: 2. Polar biomarkers in Cretan Sea surficial sediments. Marine Chemistry, 85, (1-2), 1-25.

Harzallah, A., Chapelle, A. (2002). Contribution of climate variability to occurrences of anoxia crises 'malaigues' in the Thau lagoon (southern France). Oceanologica Acta, 25, 79-86.

Hirata, S (1985). Phosphorus and metals bound to organic matter in coastal sediments-an investigation of complexes of $\mathrm{P}, \mathrm{Cu}, \mathrm{Zn}, \mathrm{Fe}, \mathrm{Mn}, \mathrm{Ni}$, Co and Ti by inductively coupled plasma-atomic emission Spectrometry with sephadex gel chromatography. Marine Chemistry, 16(1), 23-46.

Grenz, C., Alliot, E., Baudinet, D., Hélis, L., Massé, H. (1992). Impact des opérations de dévasage sur les flux de nutriments à l'interface eau-sédiment (Bassin de Thau - France). Vie et Milieu, 42, 2, 157-164.

Hecky, R.E., Mopper, K., Kilham, P., Degens, E.T. (1973). The amino acid and carbohydrate composition of diatom cell-walls. Marine Biology, 19, 323-331.

Hedges, J.I., Clark, W.A., Cowie, G.L., (1988). Organic matter sources to the water column and surficial sediments of a marine bay. Limnology and Oceanography, 33, 1116-1136. 
Hesslein, R.H. (1976). An in situ sampler for close intervale pore water studies. Limnology and Oceanograph., 21, 912914.

Hicks, R.A., Owen, C.J., Aas, P. (1994). Deposition, resuspension, and decomposition of particulate organic matter in the sediments of Lake Itasca, Minnesota, USA. Hydrobiologia, 284, 79-91.

La Jeunesse, I., Deslous-Paoli, J-M., Ximénès, M-C., Cheylan, J-P., Mende, C., Borrero, C., Scheyer, L. (2002). Changes in point and non-point sources phosphorus loads in the Thau catchment over 25 years (Mediterranean Sea France). Hydrobiologia, 475/476, 403-411.

La Jeunesse, I., Elliott, M. (2004). Anthropogenic regulation of the phosphorus balance in the Thau catchment-coastal lagoon system (Mediterranean sea, France) over 24 years. Marine Pollution Bulletin, 48, 679-687.

Li, Y., H., Gregory, S. (1976). Diffusion of ions in sea water and in deep-sea sediments. Geochimica and Cosmochimica Acta, 38, 708-714.

Maine, M., Hammerly, J., Leguizamon, M.S., Pizarro, M. (1992). Influence of the pH and redox potential on phosphate activity in the Parana Medio system. Hydrobiologia, 228, 83-90.

Mazouni, N., Gaertner, J.C., Deslous-Paoli, J.M., Landrein, S., Geringer d'Oedenberg, M. (1996). Nutrient and oxygen exchanges at the water-sediment interface in a shellfish farming lagoon (Thau, France). Journal of Experimantal Marine Biology and Ecology, 203, (2) 91-113.

Mazouni, N., Gaertner, J.C., Deslous-Paoli, J.M. (1998). Influence of oyster culture on the water column characteristics in a coastal lagoon (Thau, France). Hydrobiologia, 373/374, 149-156.

Meeuse, B.J.D. (1962). Strorage products. In Lewin R.A. (Eds) Physiology and Biochemistry of Algae. Academic Press, New-York and London, (pp. 293-299).

Mesnage, V. (1994). L'étude de la mobilité des formes de phosphate à l'interface eau-sédiment dans des écosystèmes lagunaires. phD Thesis, University of Montpellier I, 252.

Metzger, E., Simonucci, C., Jézéquel, D., Viollier, E., Sarazin, G., Prévot, F. (accepted in 2005, ECSS). Porewaters signature of biogeochemical processes in shallow marine sediment.

Mesnage, V., Picot, B. (1995). The distribution of phosphate in sediments and its relation with eutrophication of a Meditarranean coastal lagoon. Hydrobiologia, 297, 29-41.

Mudge, S. M., East, J. A., Bebianno, M. J., Barreira, L. A. (1998). Fatty acids in the Ria Formosa Lagoon, Portugal. Organic Geochemistry, 29, (4) 963-977. 
Modzeleski, J.E., Laurie, W.A. (1971). Carbohydrates from Santa Barbara Bassin: gas chromato-mass spectro analysis of trimethylsilsy derivatives. Geochimica et Cosmochimica Acta, 35, 825-838.

Moers, M.E.C., Baas, M., De Leeuw, J.W., Boon, J.J., Schenck, P.A. (1990). Occurrence and origin of carbohydrates in peat samples from a red mangrove environment as reflected by abundances of neutral monosaccharides. Geochimica et Cosmochimica Acta, 54, 2463-2472.

Oades, J.M., Kirkman, M.A.,Wagner, G.H. (1970). The use of gas-liquid chromatography for the determination of carbohydrates extracted from soils by sulfuric acid. Soil Sciences Society America Proceedings, 230-235.

Ogier, S., Disnar, J.R., Alberic, P., Bourdier, G. (2001). Neutral carbohydrate geochemistry of particulate material (trap and core sediments) in an eutrophic lake (Aydat, France). Organic Geochemistry, 32, 151-162.

Paez-Osuna, F., Bojórquez-Leyva, H., Green-Ruiz, C. (1998). Total carbohydrates : organic carbon in lagoon sediments as an indicator of organic effluents from agriculture and carbohydrate-cane industry. Environmental Pollution, 102, 2-3 321-326.

Paludan, C; Jensen, HS (1995). Sequential extraction of phosphorus in freshwater wetland and lake sediment: Significance of humic acids. Wetlands, 15(4), 365-373.

Péna, G. and B. Picot (1991). Métaux traces dans les sédiments d'une lagune méditerranénne : l'étang de Thau. Oceanologica Acta 14, 5, 459-472.

Percifal, A. (1970). Algal carbohydrates. In Pigman W. Horton D. (Eds). The Carbohydrates: Chemistry and Biochemistry, IIB. Academic Press, London,( pp. 537-568).

Plus, M., Deslous-Paoli, J.-M., Auby, I., Dagnault, F. (2001). "Factors influencing primary production of seagrass beds (Zostrera noltii Hornerm.) in the Thau Lagoon (French Mediterranean coast). Journal of Experimental Marine Biological Ecology 259: 63-84.

Rigollet, V., Sfriso, A., Marcomini, A., De Casabianca, M. L. (2004). Seasonal evolution of heavy metal concentrations in the surface sediments of two Mediterranean Zostera marina L. beds at Thau lagoon (France) and Venice lagoon (Italy). Bioresource Technology, 95,(2) 159-167.

Schmidt, S., J.-M. Jouanneau, Weber, O., Lecroart, P., Radakovitch, O., Gilbert, F., Jézéquel, D. (accepted in 2005, ECSS). Sediment dynamic at the water-sediment interface of the Thau Lagoon (South France): from seasonal to century time scales using radiogenic and cosmogenic nuclides.

Sjöström, E. (1981). Wood Chemistry, Fundamentals and Applications. (Ed.) Academic Press, London. 223 p.

Song, Y. and G. Müller (1999). Sediment-water interactions in Anoxic Freswater Sediments-Mobility of Heavy Metals and Nutrients. In : Lecture Notes in Earth Sciences, 81. (Ed.) Springer Verlag. 111 p. 
Stainton, M. P., Capel, M. J., Armstrong, F. A. J. (1977). The chemical analysis of fresh water, $2^{\text {nd }}$ Ed. Fish. Mar. Serv. Misc. Spec. Canada Publ., 25, 166 p.

Tanoue, E., Handa, N. (1987). Monosaccharides composition of marine particles and sediments from the Bering Sea and the northern North Pacific. Oceanologica Acta, 10, 91-99.

Tissot, B. P., Welte D.H. (1984). Petroleum formation and occurence. (Ed.) Springer-Verlag, Berlin, Heidelberg, NewYork, 699 p.

Treguer, P., Le Corre, P. (1975). Manuel d'analyse des sels nutritifs dans l'eau de mer. Université de Bretagne Occidentale, Brest, France 110 p.

Souchu, P., Gasc, A., Collos, Y., Vaquer, A., Tournier, H., Bibent, B., Deslous-Paoli, J-M. (1998). Biogeochemical aspects of bottom anoxia in a Mediterranean lagoon (Thau, France). Marine Ecology Progress Series, 164, $135-146$.

Weckesser, J., Drew, G. (1979). Lipopolysaccharides of photosynthetic prokaryotes. Annual Review of Microbiology, $33,215-239$.

Wicks, R.J., Moran, M.A., Pittman, L.J., Hodson, R.E. (1991). Carbohydrates signatures of aquatic macrophytes and their dissolved degradation products as determined by sensitive high-performance ion chromatography method. Applied and Environmental Microbiology, November, 3135-3143. 
Table 1

Temperature and porosity used in the flux calculation

\begin{tabular}{cccccrr}
\hline Sampling date & \multicolumn{2}{c}{ January } & & April & & June \\
\hline Sampling station & $\mathrm{C} 4$ & $\mathrm{C} 5$ & $\mathrm{C} 4$ & $\mathrm{C} 5$ & $\mathrm{C} 4$ & $\mathrm{C} 5$ \\
\hline Temperature $\left({ }^{\circ} \mathrm{C}\right)$ & 4 & 4 & 8 & 8 & 15 & $0.43 \pm 0.01$ \\
\hline Porosity & $0.61 \pm 0.03$ & $0.69 \pm 0.06$ & $0.71 \pm 0.07$ & $0.73 \pm 0.013$ & 0.01 \\
\hline
\end{tabular}


Table 2

Calculated diffusiv fluxes of Nutrients $(\mathrm{N}, \mathrm{P}), \mathrm{nm}$ : not measured

\begin{tabular}{|c|c|c|c|c|c|c|}
\hline \multirow{2}{*}{$\begin{array}{c}\text { Sampling date } \\
\text { Sampling station }\end{array}$} & \multicolumn{2}{|c|}{ January } & \multicolumn{2}{|c|}{ April } & \multicolumn{2}{|c|}{ June } \\
\hline & $\mathrm{C} 4$ & $\mathrm{C} 5$ & $\mathrm{C} 4$ & $\mathrm{C} 5$ & $\mathrm{C} 4$ & $\mathrm{C} 5$ \\
\hline$J_{S}\left(N_{4}^{+}\right)$mmol.m ${ }^{-2} \cdot \mathrm{d}^{-1}$ & $+0.2 \pm 0.05$ & $+0.62 \pm 0.1$ & $0.05 \pm 0.01$ & $+1.0 \pm 0.1$ & $\mathrm{~nm}$ & $+10.7 \pm 0.3$ \\
\hline$J_{S}\left(P O_{4}^{3-}\right)$ mmol. $\mathrm{m}^{-2} \cdot \mathrm{d}^{-1}$ & $+0.03 \pm 0.01$ & $+0.3 \pm 0.07$ & $+0.02 \pm 0.02$ & $+0.14 \pm 0.02$ & $\mathrm{~nm}$ & $+0,96 \pm 0.07$ \\
\hline
\end{tabular}


Table $3 \mathrm{a}$

Rock-Eval index (POC and HI) and neutral carbohydrate composition of sediment C5 core samples

\begin{tabular}{|c|c|c|c|c|c|c|c|c|c|c|c|}
\hline \multicolumn{4}{|c|}{ Rock-Eval } & \multicolumn{5}{|c|}{ Total neutral carbohydrate $(\%)$} & \multicolumn{2}{|r|}{ Total } & \multirow[t]{2}{*}{$\mathrm{TCH} 2 \mathrm{O}$} \\
\hline Dept & POC & HI & & & & & & & & & \\
\hline $\begin{array}{l}\mathrm{h} \\
(\mathrm{cm})\end{array}$ & $(\%)$ & $\begin{array}{l}\text { (mg HC / } \\
\text { g POC) }\end{array}$ & Arabinose & $\begin{array}{l}\text { Rhamnos } \\
\text { e }\end{array}$ & Fucose & Mannose & Galactose & Xylose & Glucose & (mg/g sed.) & $\begin{array}{l}(\mathrm{mg} / 100 \\
\mathrm{mg} \text { POC) }\end{array}$ \\
\hline $0-0.5$ & 4,4 & 367 & 7,9 & 22,6 & 22,0 & 8,0 & 10,2 & 10,5 & 18,8 & 3,59 & 8,26 \\
\hline $0.5-1$ & 4,1 & 378 & 9,4 & 28,4 & 21,9 & 6,2 & 7,6 & 11,6 & 14,9 & 3,04 & 7,46 \\
\hline $1-1.5$ & 3,9 & 372 & 7,4 & 24,6 & 17,5 & 8,4 & 17,6 & 11,2 & 13,4 & 3,23 & 8,37 \\
\hline $1.5-2$ & 3,3 & 372 & 10,0 & 22,4 & 22,0 & 9,0 & 11,4 & 13,5 & 11,6 & 3,20 & 9,81 \\
\hline $2-3$ & 3,3 & 364 & & & & & & & & & \\
\hline $3-4$ & 3,2 & 359 & & & & & & & & & \\
\hline $4-5$ & 2,9 & 372 & & & & & & & & & \\
\hline $5-6$ & 2,7 & 360 & & & & & & & & & \\
\hline $6-7$ & 2,4 & 351 & & & & & & & & & \\
\hline $7-8$ & 1,7 & 323 & & & & & & & & & \\
\hline $8-9$ & 1,9 & 311 & & & & & & & & & \\
\hline $9-10$ & 2,2 & 217 & & & & & & & & & \\
\hline $10-11$ & 1,9 & 245 & & & & & & & & & \\
\hline $11-12$ & 2,0 & 279 & & & & & & & & & \\
\hline $12-13$ & 2,3 & 235 & & & & & & & & & \\
\hline $13-14$ & 1,8 & 276 & 23,7 & 17,9 & 34,8 & 4,3 & 3,7 & 8,6 & 7,0 & 2,23 & 12,4 \\
\hline $14-15$ & 1,6 & 335 & 7,7 & 20,6 & 18,3 & 13,0 & 7,3 & 15,4 & 17,7 & 1,46 & 9,04 \\
\hline $15-16$ & 2,2 & 260 & 21,2 & 19,5 & 30,3 & 3 & 4,4 & 7,95 & 13,7 & 1,9 & 8,5 \\
\hline $16-17$ & 1,7 & 305 & 10.3 & 16.6 & 19,9 & 10,4 & 14,4 & 13 & 15,4 & 1,6 & 9,4 \\
\hline $17-18$ & 1,5 & 324 & 14 & 21.7 & 26,5 & 9,9 & 6,5 & 8,1 & 13,2 & 1,5 & 9,8 \\
\hline 18-19 & 1,9 & 246 & 7.6 & 12.4 & 15,2 & 14 & 16,4 & 14,9 & 19,5 & 1,6 & 8,2 \\
\hline $20-21$ & 1,8 & 258 & 14.3 & 26.7 & 23,3 & 6 & 6,3 & 13,5 & 9,8 & 1,2 & 7 \\
\hline
\end{tabular}


Table $3 b$

Rock-Eval index (POC and HI) and neutral carbohydrate composition of sediment $\mathrm{C} 4$ core samples

\begin{tabular}{|c|c|c|c|c|c|c|c|c|c|c|c|}
\hline \multirow[b]{2}{*}{$\begin{array}{l}\text { Depth } \\
(\mathrm{cm})\end{array}$} & \multicolumn{2}{|c|}{ Rock-Eval } & \multicolumn{7}{|c|}{ Total neutral carbohydrate $(\%)$} & \multirow{2}{*}{$\begin{array}{c}\text { Total } \\
\begin{array}{c}\mathrm{mg} / \mathrm{g} \\
\text { sed. })\end{array}\end{array}$} & \multirow{2}{*}{ 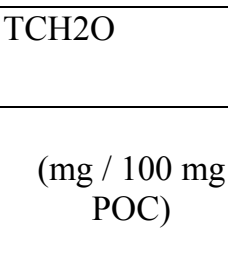 } \\
\hline & $\begin{array}{l}\text { POC } \\
(\%)\end{array}$ & $\begin{array}{l}\text { HI } \\
(\mathrm{mg} \mathrm{HC} / \mathrm{g} \\
\mathrm{POC})\end{array}$ & $\begin{array}{l}\text { Arabinos } \\
\text { e }\end{array}$ & $\begin{array}{l}\text { Rhamnos } \\
\text { e }\end{array}$ & Fucose & Mannose & $\begin{array}{c}\text { Galactos } \\
\mathrm{e}\end{array}$ & Xylose & Glucose & & \\
\hline $0-0.5$ & 3,0 & 354 & 8,9 & 1,8 & 29,0 & 9,6 & 13,2 & 13,2 & 24,5 & 2,52 & 8,41 \\
\hline $0.5-1$ & 3,0 & 347 & 14,4 & 8,9 & 18,1 & 10,1 & 11,5 & 13,8 & 23,2 & 2,09 & 6,87 \\
\hline $1-1.5$ & 3,2 & 341 & 12,0 & 13,8 & 22,5 & 9,6 & 11,7 & 8,0 & 22,4 & 2,52 & 8,01 \\
\hline $1.5-2$ & 3,2 & 352 & 7,3 & 8,6 & 16,6 & 10,2 & 15,1 & 18,0 & 24,3 & 1,70 & 5,35 \\
\hline $2-3$ & 3,1 & 338 & & & & & & & & & \\
\hline $3-4$ & 2,9 & 342 & & & & & & & & & \\
\hline $4-5$ & 2,7 & 353 & & & & & & & & & \\
\hline $5-6$ & 2,8 & 333 & & & & & & & & & \\
\hline $6-7$ & 2,7 & 336 & & & & & & & & & \\
\hline $7-8$ & 2,5 & 336 & & & & & & & & & \\
\hline $8-9$ & 2,6 & 317 & & & & & & & & & \\
\hline $9-10$ & 2,6 & 307 & & & & & & & & & \\
\hline $10-11$ & 2,6 & 314 & & & & & & & & & \\
\hline $11-12$ & 2,8 & 315 & & & & & & & & & \\
\hline $12-13$ & 3,1 & 304 & 14,6 & 14,0 & 25,8 & 8,2 & 7,8 & 14,1 & 15,6 & 1,81 & 6,89 \\
\hline $13-14$ & 3,0 & 319 & 0,9 & 15,6 & 15,9 & 9,4 & 18,0 & 12,0 & 28,2 & 2,52 & 9,12 \\
\hline $14-15$ & 3,1 & 286 & 6,8 & 17,8 & 17,7 & 9,3 & 13,0 & 12,0 & 23,5 & 3,17 & 10,33 \\
\hline $15-16$ & 3,8 & 264 & 6,3 & 11,8 & 15,1 & 10,0 & 15,5 & 14,4 & 27,0 & 3,23 & 10,67 \\
\hline $16-17$ & 2,7 & 306 & 6,7 & 15,7 & 15,2 & 10,6 & 16,9 & 12,5 & 22,4 & 3,03 & 9,77 \\
\hline $17-18$ & 2,7 & 303 & 10,7 & 19,8 & 19,8 & 6,6 & 9,1 & 17,7 & 16,3 & 2,31 & 6,09 \\
\hline $18-19$ & 2,6 & 354 & 10,4 & 16,2 & 23,2 & 5,5 & 13,3 & 14,8 & 16,7 & 2,15 & 7,93 \\
\hline $20-21$ & 2,8 & 347 & 10,2 & 21,3 & 17,3 & 12,5 & 15,4 & 15,5 & 7,9 & 2,27 & 8,39 \\
\hline
\end{tabular}


Table 4

Literature sources for Potentiel sources of OM, through Neutral Carbohydrate association

\begin{tabular}{lll}
\hline \multicolumn{1}{c}{ Potential sources } & \multicolumn{1}{c}{$\begin{array}{c}\text { Neutral carbohydrate } \\
\text { association }\end{array}$} & \multicolumn{1}{c}{ Réferences } \\
\hline Terrestrial plant tissues & $\begin{array}{l}\text { Arabinose, Mannose, } \\
\text { Galactose, Xylose and } \\
\text { Glucose }\end{array}$ & Sjöström, 1981 \\
\hline Bacteria & $\begin{array}{l}\text { Rhamnose, Fucose and } \\
\text { glucose }\end{array}$ & $\begin{array}{l}\text { Barkers \& Somers, 1970 } \\
\text { Boon et al., 1983 } \\
\end{array}$ \\
& & $\begin{array}{l}\text { Bhosle et al., 1983 } \\
\text { Hicks et al., 1994 }\end{array}$ \\
& Ogier et al., 2001 \\
& Weckesser \& Drew, 1979 \\
\hline Phytoplankton & & Percifal, 1970 \\
Diatoms & & Cowie \& Hedges, 1984 \\
& & Meeuse, 1962 \\
& & Bölter \& Dawson, 1982 \\
& & Hecky et al., 1973 \\
& & Moers et al., 1990 \\
& & Tanoue \& Handa, 1987 \\
\hline
\end{tabular}




\section{Figures Caption -}

Figure 1 : Location of the study site : the « Thau » Lagoon (France).

Figure 2 : Porewater profiles of Soluble Reactiv Phosphate (SRP) versus depth at the C5 sampling station (a) in winter, (b) in spring, (c) in summer; and at the C4 sampling station (d) in winter, (e) in spring. Two diffusion samplers have been deployed at each season and sampling station giving two profiles except in winter at C5 (a).

Figure 3 : Porewater profiles of ammonia $\left(\mathrm{NH}_{4}^{+}\right)$versus depth at the $\mathrm{C} 5$ sampling station (a) in winter, (b) in spring, (c) in summer; and at the C4 sampling station (d) in winter, (e) in spring. Two diffusion samplers have been deployed, giving two profiles, at each season and sampling station except in winter and spring at C5 (a, b), in winter at C4 (d).

Figure 4 : Porewater profiles of Diossolved Organic Carbon (DOC) versus depth at the C5 sampling station (a) in winter, (b) in spring, (c) in summer; and at the C4 sampling station (d) in winter, (e) in spring. Two diffusion samplers have been deployed at each season and sampling station.

Figure 5 : POC (\%) and $\mathrm{HI}\left(\mathrm{mg} \mathrm{HC} \mathrm{g}^{-1} \mathrm{POC}\right)$ at the $\mathrm{C} 5$ station (a), and at the $\mathrm{C} 4$ station (b).

Figure 6 : Average weight percentages of individual neutral carbohydrates, in $\mathrm{C} 5$, (a) at the surficial sediment $(0-2 \mathrm{~cm})$ and $(\mathrm{c})$ at the end of the core $(13-22 \mathrm{~cm})$; and in $\mathrm{C} 4,(\mathrm{~b})$ at the surficial sediment $(0-2 \mathrm{~cm})$ and $(\mathrm{d})$ at the end of the core $(10-20 \mathrm{~cm})$. 
Figure 1 : Location of the study site : the « Thau » Lagoon (France)

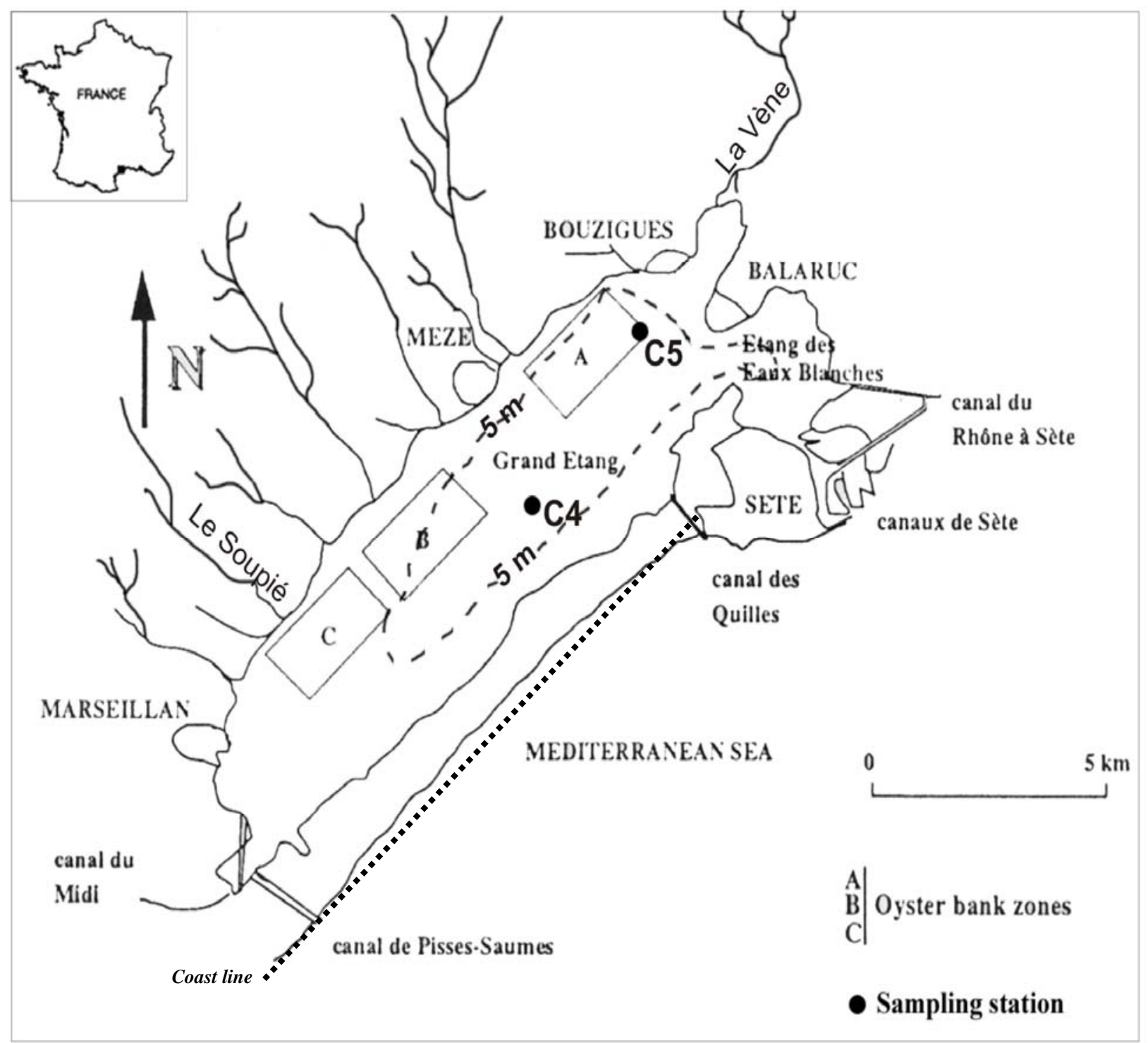


Figure 2 : Porewater profiles of Soluble Reactiv Phosphate (SRP) versus depth at the C5 sampling station (a) in winter, (b) in spring, (c) in summer; and at the C4 sampling station (d) in winter, (e) in spring. Two diffusion samplers have been deployed at each season and sampling station giving two profiles except in winter at C5 (a).

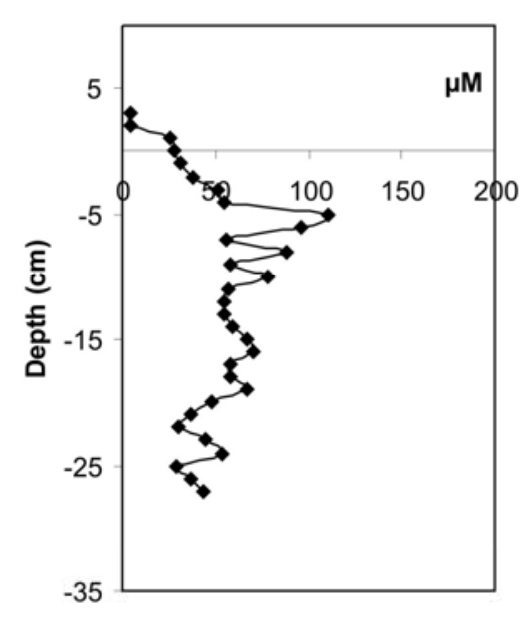

(a)

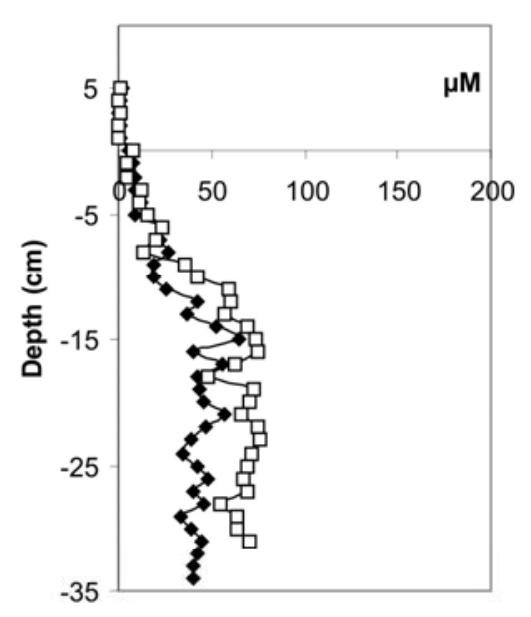

(b)

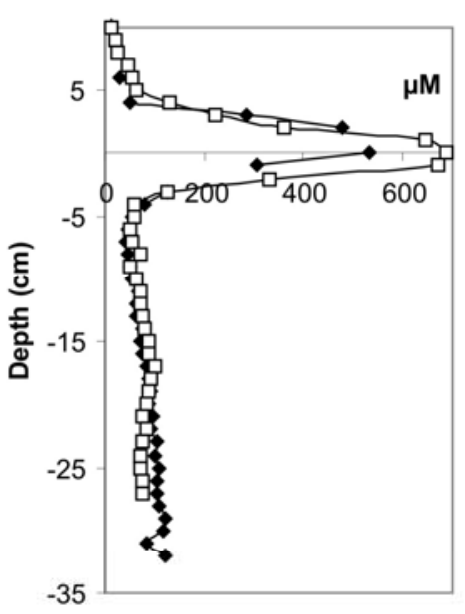

(c)

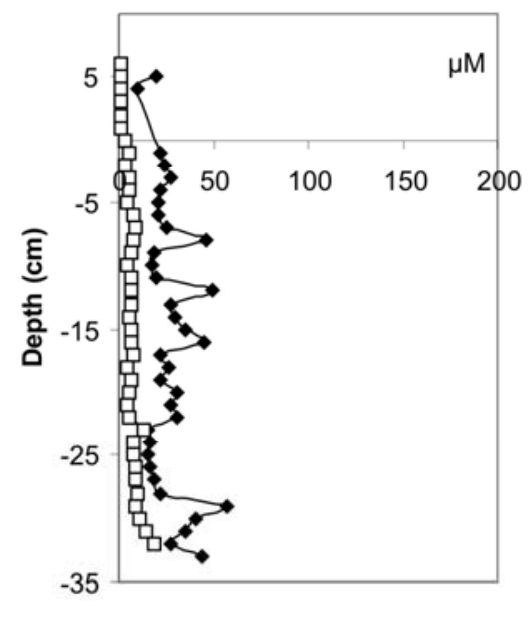

(d)

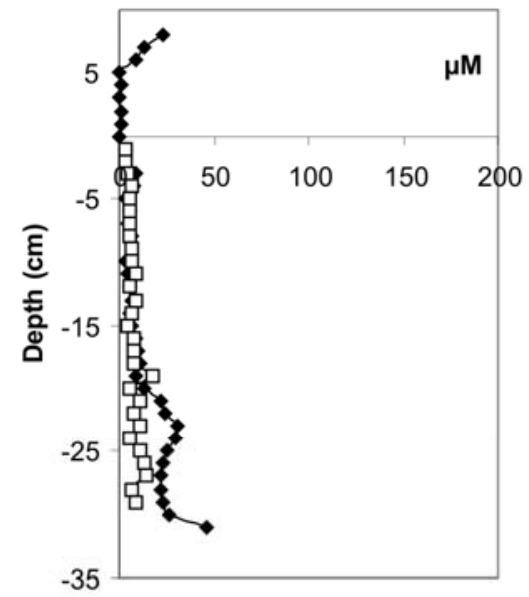

(e) 
Figure 3 : Porewater profiles of ammonia $\left(\mathrm{NH}_{4}^{+}\right)$versus depth at the $\mathrm{C} 5$ sampling station (a) in winter, (b) in spring, (c) in summer; and at the C4 sampling station (d) in winter, (e) in spring. Two diffusion samplers have been deployed, giving two profiles, at each season and sampling station except in winter and spring at C5 (a, b), in winter at C4 (d).

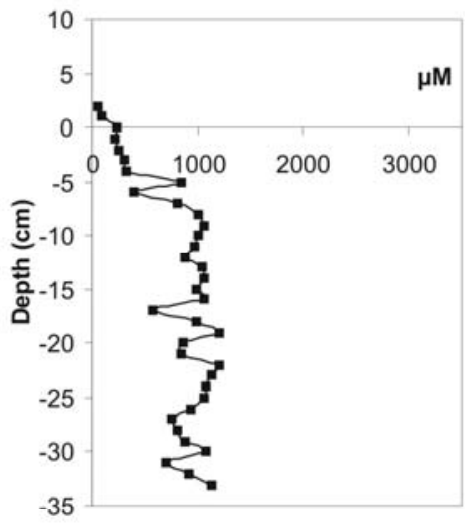

(a)

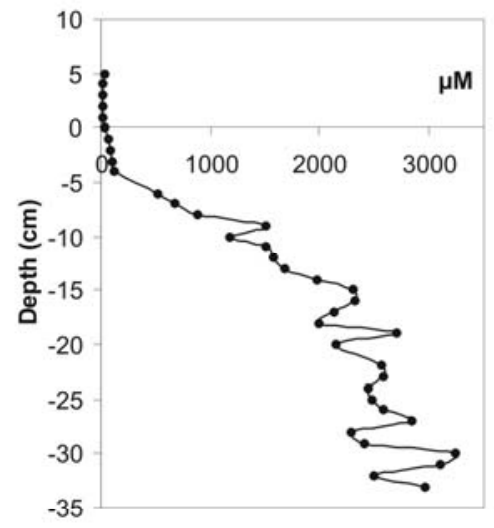

(b)

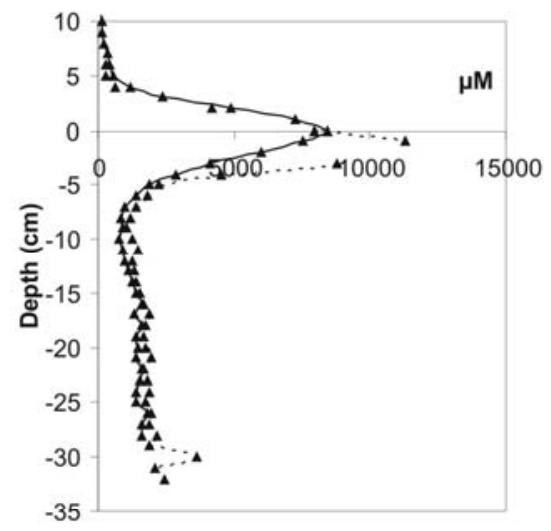

(c)

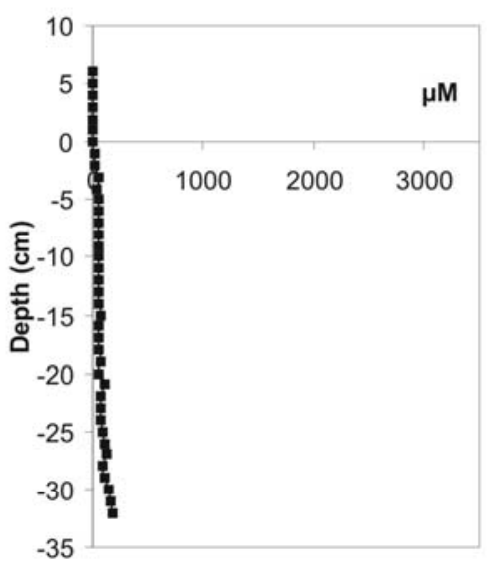

(d)

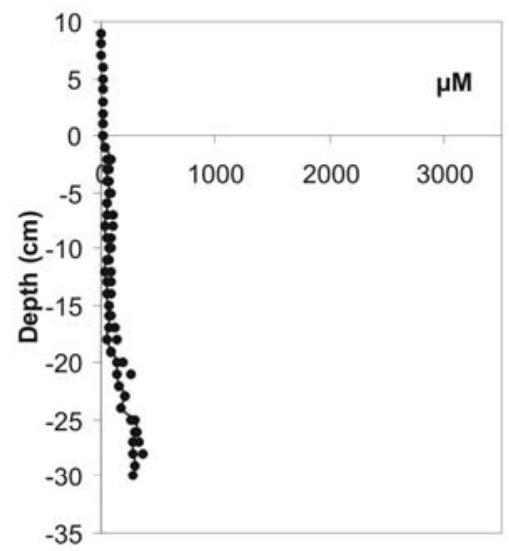

(e) 
Figure 4 : Porewater profiles of Diossolved Organic Carbon (DOC) versus depth at the C5 sampling station (a) in winter, (b) in spring, (c) in summer; and at the C4 sampling station (d) in winter, (e) in spring. Two diffusion samplers have been deployed at each season and sampling station.

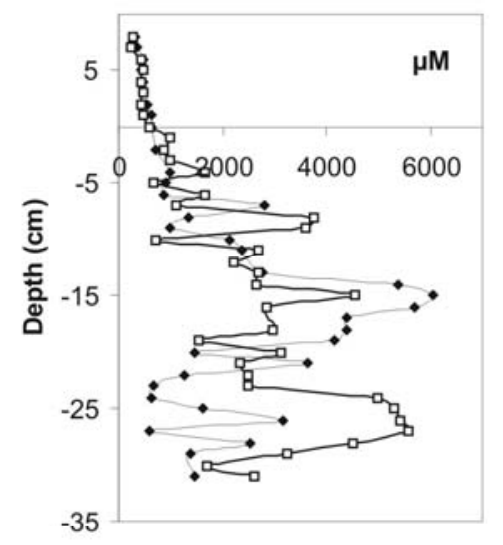

(a)

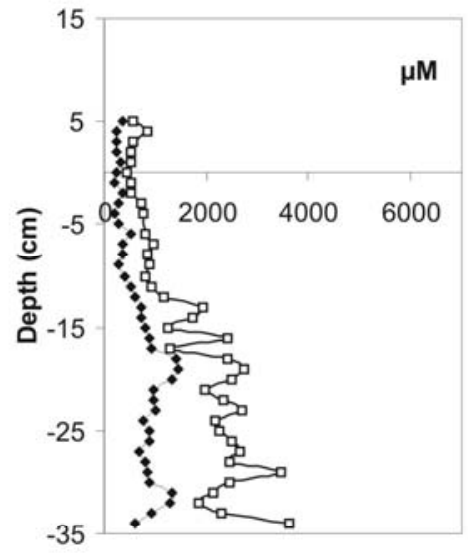

(b)

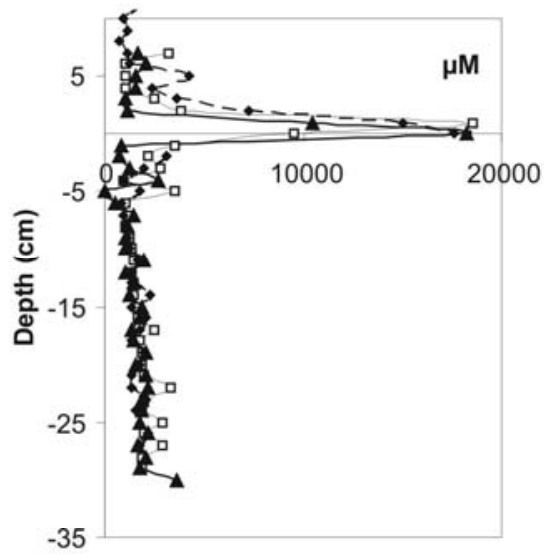

(c)

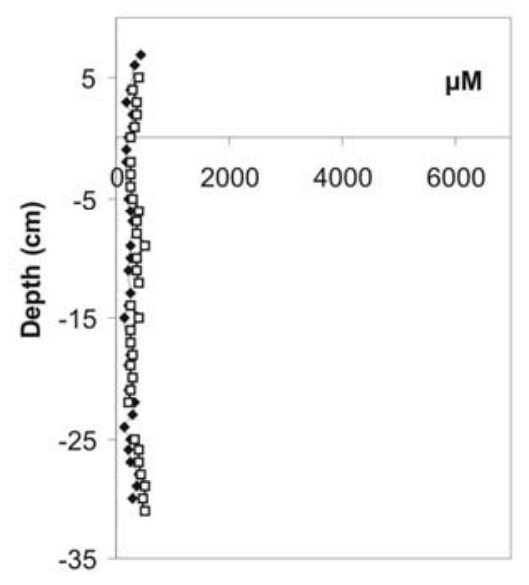

(d)

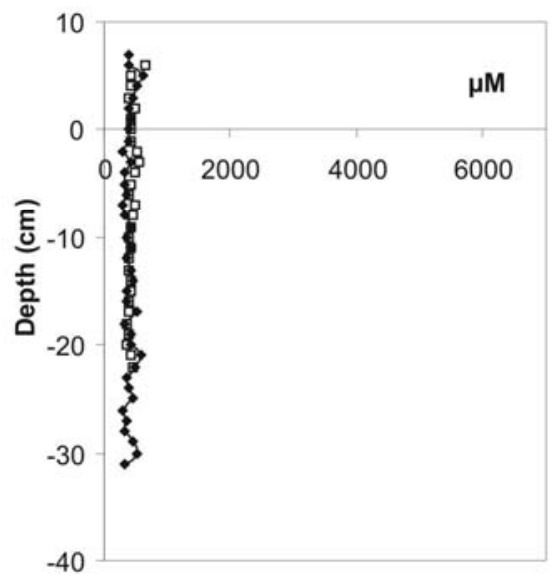

(e) 
Figure 5 : POC (\%) and $\mathrm{HI}\left(\mathrm{mg} \mathrm{HC} \mathrm{g}^{-1} \mathrm{POC}\right)$ at the $\mathrm{C} 5$ station (a), and at the $\mathrm{C} 4$ station (b)

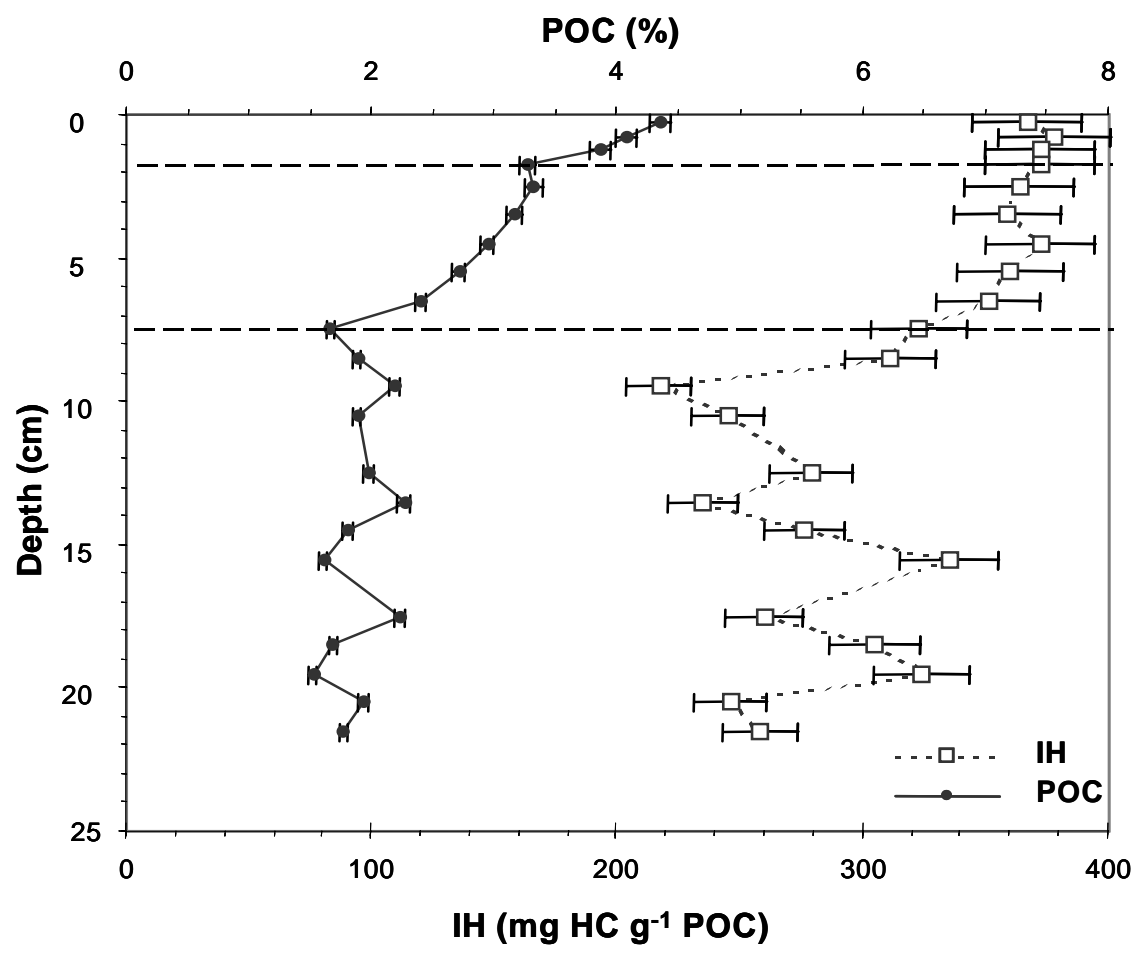

(a)

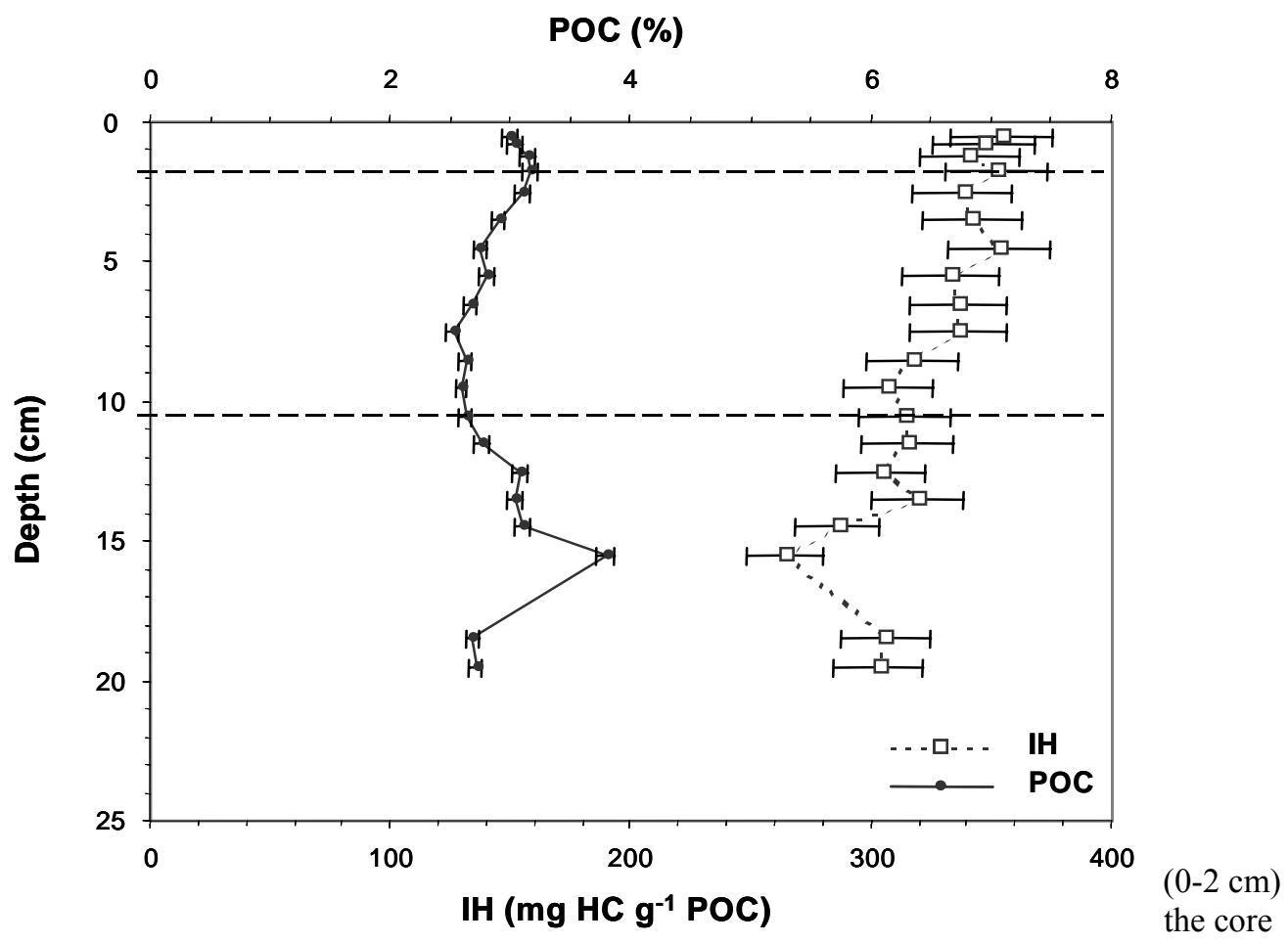

and $(\mathrm{c})$ at the end of th $(10-20 \mathrm{~cm})$.

(b) 


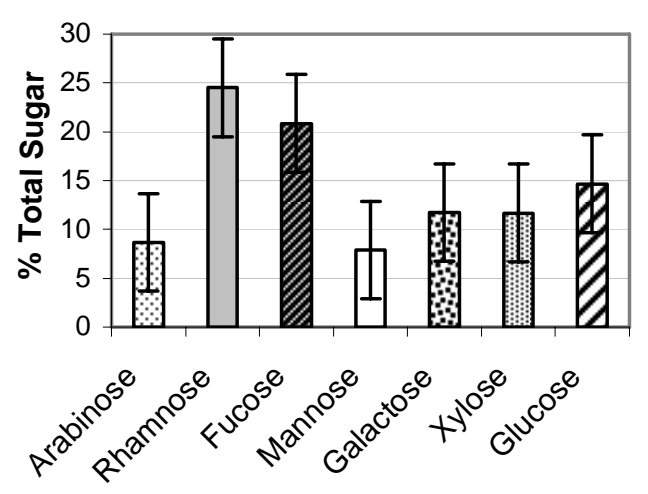

(a)

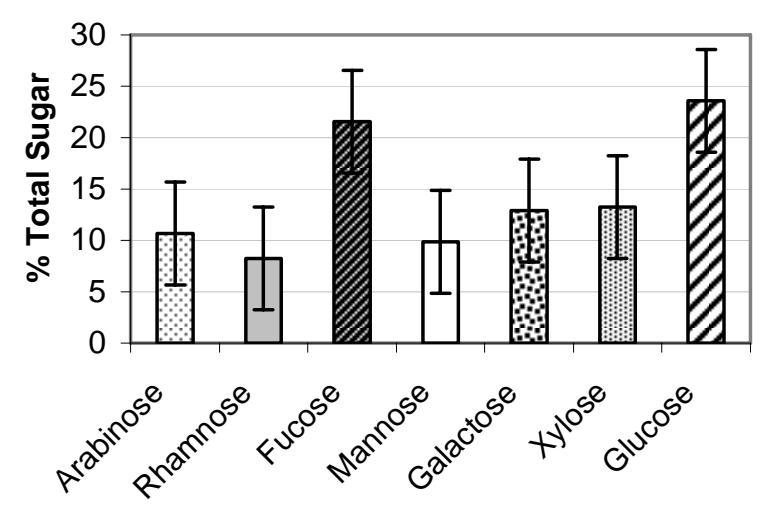

(b)

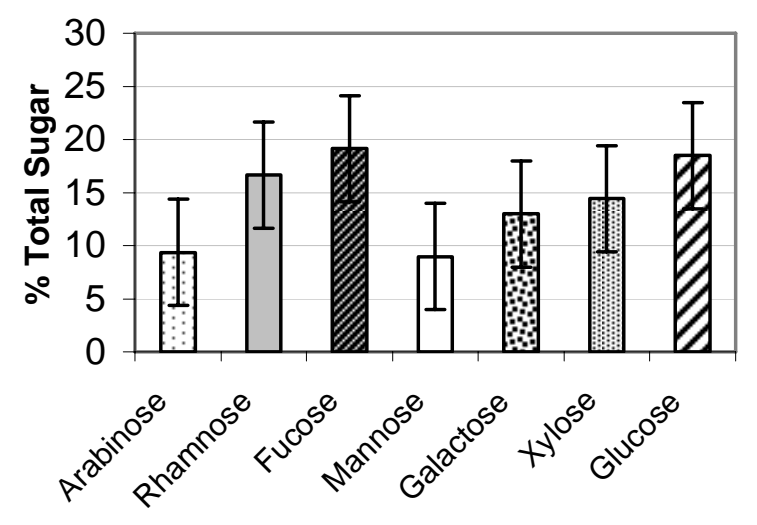

(c)

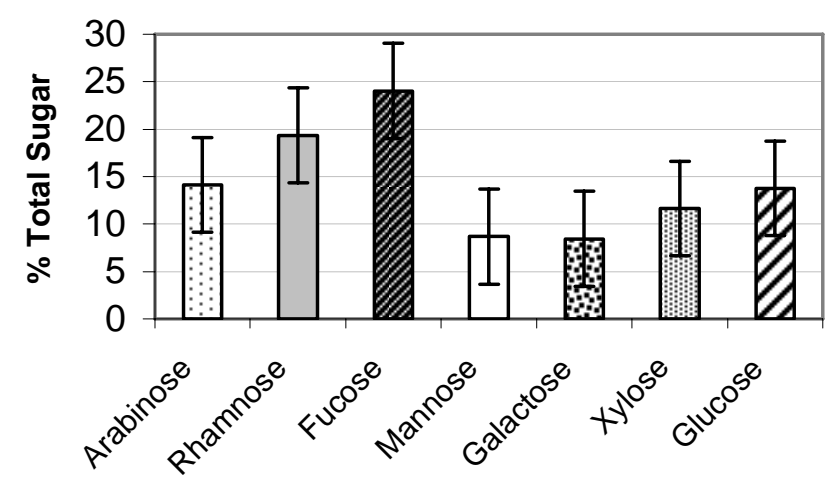

(d) 